\title{
THE DETECTION AND PREVENTION OF MANIPULATIONS IN THE BALANCE SHEET AND THE CASH FLOW STATEMENT
}

\author{
Dragomir Dimitrijevic* \\ Faculty of Economics, University of Kragujevac, Kragujevac, The Republic of Serbia
}

Financial statements which consist of objective, real and reliable information represent the key basis for making many business decisions. If, when writing financial statements, certain manipulation techniques are used for displaying the best possible results of transactions, the quality of financial reports will be endangered. Many financial frauds have led to a great mistrust in the system of financial reporting and the profession of accounting and auditing, which are often accused of the emergence of fraud and losing trust in the reliability of financial information by many users and economic decision makers. These are the reasons why the paper discusses the techniques of manipulation in financial statements, especially in balance sheets and cash flow statements, since these forms of manipulation are harder to detect and prevent when compared to manipulations of revenues and expenses in the income statement.

Keywords: balance sheet, cash flow statement, financial reporting, manipulations, techniques of manipulations

JEL Classification: M48, K42

\section{INTRODUCTION}

Frauds in a company's operations are most often related to manipulation positions in financial statements. Big financial scandals, which broke at the beginning of the 21st century - Enron, Worldcom (Stančić, Dimitrijević, Stančić, 2013, 1895), led to losses of several billion dollars. Not only did the owners and creditors of the companies in which frauds were committed suffer losses, but also various economies around the world

\footnotetext{
* Correspondence to: D. Dimitrijevic, Faculty of Economics, University of Kragujevac, D. Pucara 3, 34000 Kragujevac, The Republic of Serbia; e-mail: dimitrijevicd@kg.ac.rs
}

within which these companies operated. A financial statement manipulation is performed with the aim of displaying a false financial position, performance, and cash flows of a company. The greatest responsibility for a financial statement manipulation is held by a company's management. The most frequent excuse of the management for committing a fraud is that it was a way to try to save the company and ensure a profit for the company's owners. The most frequent forms of manipulation include increasing a revenue, decreasing expenses, the increasing and falsifying of receivables, reducing or not showing liabilities, increasing the value of inventories, counterfeiting the inflow and outflow of money from the company and many others. 
These are only some of the forms of manipulation in financial statements by which the management wants to show the best possible business results. However, many examples of financial frauds pointed that behind all these manipulations there is the wish of the management to accomplish their personal goals, such as achieving extra bonuses related to the result of business operations, their desire for additional wealth, the securing of their job positions, the greed of an individual, the wish to have a better life standard than their own financial possibilities allow them, the existence of personal debts, bad creditworthiness, a personal financial loss and the like.

By analyzing various cases of fraud incurred by financial statements manipulation, it can be seen that the techniques of manipulation mostly used were frauds related to the revenue and expenses in the income statement. Manipulations with revenues and expenses are "simpler" for fraudsters because there are a great number of techniques for manipulation; this is a way to directly and in a short period of time influence the financial results of a company and by doing so to accomplish the personal goals of the management more rapidly and more easily. However, since the revenues and expenses in income statements are most frequently the "target" of fraudsters, various control bodies (internal and external audit, public authorities, and forensic accountants) handle a great number of techniques by which they detect and prevent manipulations in revenues and expenses. On the other hand, the positions of other financial statements, especially the balance sheet and cash flow statements, are also objects of manipulations. Still, practice has shown that these manipulations are much rarer in relation to manipulations in cash flow statements. This does not mean that they are not applied, but rather that they are harder to detect and that they are only applied by fraudsters capable of the skillful concealment of evidence.

It is exactly the techniques of detecting and preventing manipulations in the balance sheet and cash flow statements that are the subject of the analysis carried out in the paper. All of the positions in a balance sheet can be objects of manipulation. However, it has been shown that inventories, cash and liabilities are most often objects of manipulation. On the other hand, all the inflows and outflows of money, which are shown in cash flow statements, can be manipulated, but practice has shown that an increase in the inflow and a decrease in the outflow on the basis of operating activities are in the majority of cases the most frequent techniques of manipulation in cash flow statements.

The aim of the research in this paper is to identify the possibilities of and instruments for preventing and detecting manipulations in balance sheets and cash flow statements. That every manipulation in revenues and expenses in balance sheets either directly or indirectly influences assets, equity and liabilities, as well as the inflow and outflow of money has to be taken into account. However, this paper presents the manipulation techniques which directly influence the positions in a balance sheet and a cash flow statement with the aim to show the best business result possible and a more beneficial financial situation of a company.

In accordance with the established topic and aim of the research, the paper starts with the following hypotheses:

H1: The most widely used manipulations in balance sheets, which are used to directly influence the business result and the financial position of a company, are manipulations of inventories, liabilities and cash.

H2: The manipulation techniques of the inflow and outflow of money in cash flow statements are much harder to detect and prevent than other forms of manipulation.

The established hypotheses will be tested by applying the qualitative methodology of research based on a descriptive analysis. Starting from the relevant literature consisting of theoretical discussions and from case studies, general conclusions on the discussed problem will be derived. What will be of special significance is the method of induction, which will, starting from concrete instances of manipulation, lead to the derivation of a general conclusion about all the techniques of manipulation used in balance sheets and cash flow statements. Therefore, by analyzing the already applied manipulation techniques, it is to be pointed out to the possibility of the simpler and faster 
detection and prevention of these and similar forms of manipulation in the future.

The paper is composed of six parts. After the introductory discussions, in the second part there is a list of the relevant literature about the term, importance and techniques of manipulation in financial statements. In the third part, the manipulation techniques in balance sheets are discussed, with a special analysis of the manipulation techniques of inventories, liabilities and cash. The most frequent methods of the manipulation of the inflow and outflow of money in cash flow statements are the subjects of the analysis in the fourth part. The manipulation techniques of the inflow and outflow from the operating activities of a company are analyzed in detail. The fifth part includes an analysis of the methods of the prevention of all forms of a fraud, and thus of frauds in financial statements. In the end, the standpoints on the fulfillment of the hypotheses are presented and it is pointed to the contribution of the work.

\section{THEORETICAL ASPECTS}

The system of financial reporting represents the only complete quantitative system comprised of all the business transactions executed within a company as well as transactions with individuals, companies and institutions in the environment (Malinić, 2009a, 139). Financial reporting is the exclusive responsibility of the management and a powerful instrument for various adjustments for the purpose of displaying an image of a business subject as a better one than it actually is. This is all aimed at attracting potential investors, getting convenient loans more easily, increasing the price of shares on the stock exchange and the like (Dmitrovic Šaponja, Milutinović, Šijan, 2007). "Changing the balance sheet”, "earnings management”, „cooking the books" are the terms used for explaining the procedures oriented towards the manipulation of financial statements in order to achieve certain goals. They can subsume a wide spectrum of legal and illegal managing procedures (Petrova, 2008, 24). Financial embezzlement is a phenomenon that has its own motives, and a fertile ground for a destructive action is more convenient in a weakly -organized financial reporting environment (Milojević, 2009, 41).

A number of financial frauds and scandals from the end of the last and the beginning of the 21st century, as well as the emergence of the global financial and economic crisis, have put to attention that it is necessary that financial and accounting information should contain certain main characteristics: comprehensibility, relevance, reliance, comparability and consistency (Radulović, 2010, 27). Manipulations in financial statements can impact even the most developed capital markets and lead to a bigger or smaller financial crisis and a disturbance in their functioning. Fraudulent financial statements have existed since the beginning of financial reporting because they have been used for achieving certain short -term material goals of the management or the owner. They are present not only in transition countries, but also in countries with developed economies and the system of financial reporting. The basic goal of the financial statement manipulation is to gain some benefits for fraudsters by showing a wrong image about the financial situation of a company and its profitability and in this form of criminal action, some of the users of financial statements (creditors, investors) are the damaged party taking the risk of losing financial means by being led to make wrong decisions (Jakšić, Vuković, 2012, 414).

According to the International Standards on Auditing, fraudulent financial reporting represents a criminal act characterized by the intentional misstatement or omission of certain information or a disclosure in financial statements (International Standards and Audit Announcements, 2005, 277). The Association of Certified Fraud Examiners (ACFE) defines fraudulent financial reporting as the „intentional misstatement of material facts or accounting information, which leads the user of financial information, presented in the financial statements, to make wrong decisions" (Zabihollah, 2002, 2). The American Institute of Certified Public Auditors (AICPA) defines fraudulent financial reporting as the „intentional incorrectness or omission of the amount or disclosure in financial statements in order to deceive the users of financial statements." This may include (Stefanović, 2000, 4): 
- he manipulation, falsification or editing of accounting records or accompanying documents used in the preparation of financial statements;

- the incorrect (false) presentation or intentional omission of significant events or transactions from financial statements;

- the Intentionally wrong application of accounting rules.

Frauds in financial statements may arise from (Wells, 2005, 324):

- falsifying material facts, documents or business transactions;

- the misstatement of events, transactions, accounts or other significant information on the basis of which financial statements are made;

- the intentionally wrong use of the accounting principles, policies or procedures applied for the evaluation, recognition and recording of business transactions;

- the false presentation of financial information in financial statements.

\section{MANIPULATIONS IN BALANCE SHEETS}

The most frequent forms of malversation that occur in companies and are connected with the categories in balance sheets are the overestimation of receivables, the manipulation of the inventories of materials, goods and final products, the overestimation and underestimation of liabilities, the absence of liabilities records etc. Manipulations made in balance sheets are either directly or indirectly connected with the manipulations of revenues and expenses in balance sheets and with the cash flow in cash flow statements. In other words, it is impossible to manipulate particular elements from balance sheets without influencing revenues and expenses. If a fraudster wants to hide his/her criminal acts, they need to "conceal" the trace of such manipulations in every financial statement in which the fraud in question is involved. For example, if a certain account payable is omitted, it affects a decrease in future expenses and the outflow of cash that would occur when paying for this liability. However, this concealed account payable results in an increase in a certain part of assets which also needs to be omitted from the balance. This indicates that frauds in balance sheets are so complex that they are hard to detect if fraudsters have successfully hidden all the „evidence" of it.

When it comes to tangible and intangible assets, the effect on their value is, on the part of the management and accountants, most often realized by an incorrect application, or more precisely, the abuse of the rules for the activation of the expenses executed in connection with these assets or by an overestimation, i.e. an underestimation of the residual value of the assets, their duration period and the choice of the methods of amortization. Within the scope of IAS 16 - Property, plant, and equipment, IAS 38 - Intangible assets, IAS 23 - Borrowing costs, IFRS 3 - Business combinations, there are requirements for the activation of expenses connected with tangible and intangible investments from which an inflow of the economic benefit is expected. In other words, capitalization by itself is not an instrument for accomplishing frauds in financial statements. The activation of additional investments into fixed assets, interest costs, investment in development costs, as the most common expenditures that are capitalized, become an instrument of fraud if not implemented with the standard - prescribed conditions for capitalization (Škarić Jovanović, 2011, 218). The previously stated possibilities of influencing the result and the equity of a company by overestimating its assets and underestimating its liabilities are potential causes for a bigger or smaller violation of the propositional power of the balance. The problem is the fact that this behavior creates hidden losses and that the balances burdened with those hidden losses lead investors towards making wrong decisions through an unreal presentation of the real earning and financial position of the company. The objectification of high hidden losses often means the end for a company (Malinić, 2009b, 58).

The typical examples of the overestimation of assets and the underestimation of liabilities are accounted for in Figure 1. 


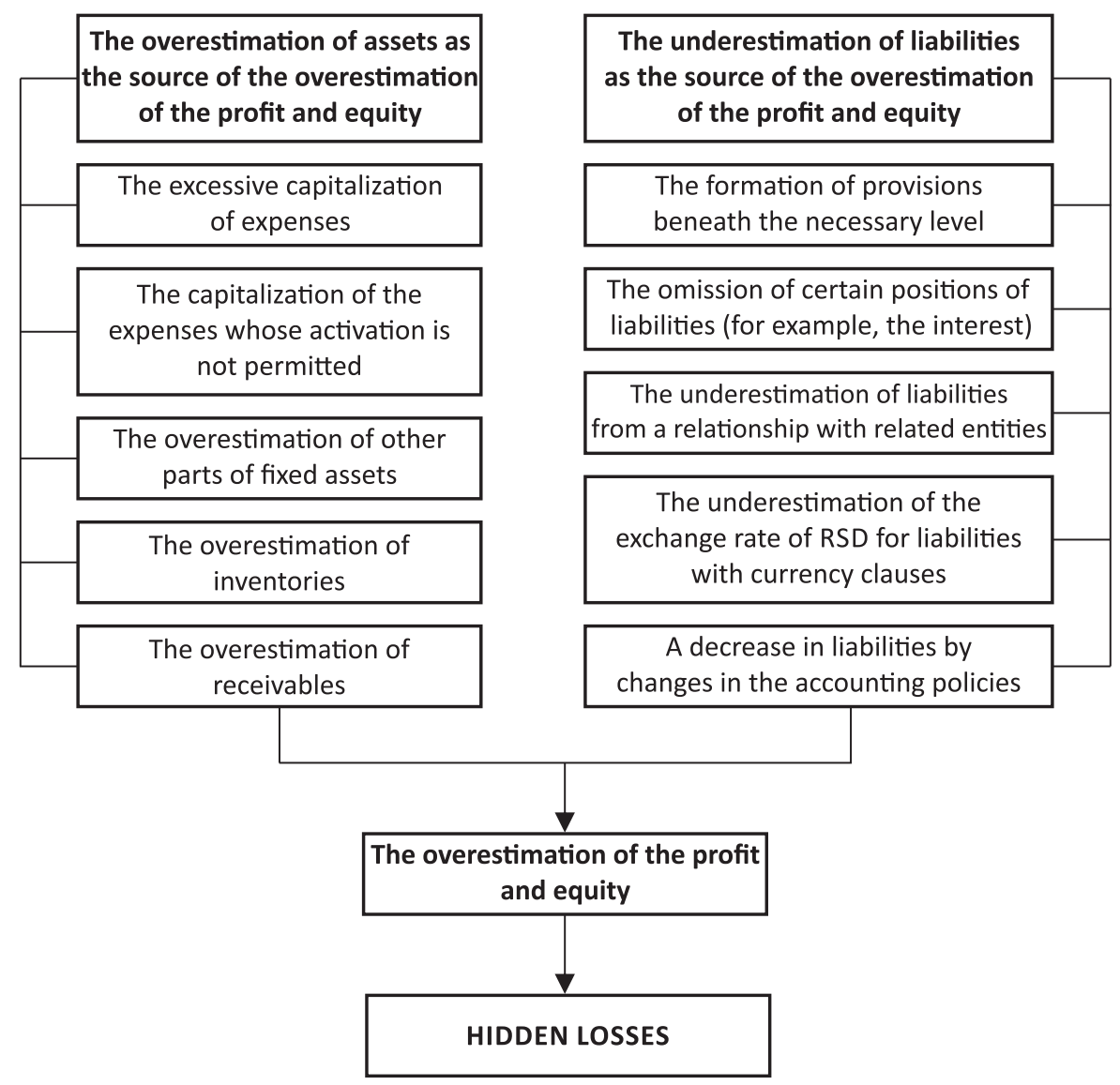

Figure 1 The overestimation of assets and the underestimation of liabilities as the sources of an unreal increase in the profit and the capital

Source: Malinić, 2009b, 57

Inventories are a very important element of a company's business performance. The success of a company's business depends on the proper and efficient management of inventories. More precisely, if a company obtains the necessary level of inventories and does not "block" its own money in them, it will lead to better business results, other conditions being equal. Also, many financial institutions have made a condition of taking some of the inventories as pawn for giving loans, and therefore they are interested in the flow of inventories and their influence on the result of the business. If frauds regarding all these forms of inventories are taken into consideration, then the illegal appropriation of inventories can be said to be possible to perform by:
Forming false requisitions - Under false requisitions, the fraudster takes from the inventories a greater amount than necessary with the aim to illegally keep or sell that redundancy;

Making a fictional sale - It involves false invoices usually addressed to dummy corporations or accomplice firms. This manipulation solves the problem of the shortage of inventories and also the one of inflating revenues from the sales incurred by false invoices;

Illegal appropriation during the purchase and reception of inventories - During the purchase and reception of inventories, the fraudster knowingly 
keeps one part of the inventories. In order to conceal this manipulation, the falsified documentation is formed during the reception of the purchased inventories. One of the possible ways to perform this form of fraud is when the person who is in charge of the reception of the purchased material assets falsifies the reception documents which show that instead of, for example, the actual 1,000 units of goods only 900 of such goods came from the supplier, and by this, he or she appropriates the remaining 100 units for themselves. An obvious problem in this case is that the reception document will not match the supplier's invoice and hence there will be a payment problem. In this example, if the supplier's invoice states that there are 1,000 units of goods, but the reception document shows the reception of 900 units, this lack will have to be explained. The problem for the fraudster is that the supplier can claim that the delivery was fully accomplished. In this case, on certain conditions, the fraudster can avoid the problem by changing only one copy of the reception document. The copy of the document sent to the accountant would show the full reception of the goods and the supplier would be fully paid, but the copy sent to the inventory accounting would be false and reduced by the appropriated amount. By this, the real state of goods in the warehouse would match the documents in the inventory accounting. This is a simplified example of a fraud which can only be accomplished in companies with weak internal control and during the purchase of goods which are individually very expensive, but easily sold (Petković, 2010, 213);

The evaluation of materials inventory - The most widely used manipulation is a frequent change of the methods of the calculation of the output value of inventories because by frequent changes of these methods, different effects in income statements are shown. What is primarily meant here is a situation in which a company changes its accounting policy of calculating the inventory output in short periods of time. For instance, in the previous year, for the same kind of inventories, a company used the FIFO model when calculating the output, and in the next year, it is the method of the weighted average expense. IAS 2 allows the application of both methods, but that does not mean that they should be applied to one kind of inventories alternately. The FIFO method implies that the output of inventories is calculated by taking the first input price for the first output, and so on, while in the case of the method of weighted average expenses, the price taken for every single output is the one calculated by multiplying the amount and the price of a concrete kind of inventories which preceded the output (Urošević, 2010, 54).

Liabilities are inevitable in every company. The ability of a company to execute its liabilities on time indicates the healthy financial position of the company. On the other hand, problems in executing these liabilities indicate problems in the company's business. Some liabilities bring, by their own appearance, changes only within the balance sheet, which means that there is an increase in assets. In another case, they arise together with the occurrence of expenses, which means that changes extend to both the balance sheet and the income statement. A susceptibility to fraud regarding liabilities is larger if operations related to fraud can extend to both the balance sheet and the income statement. Different liabilities give different manipulation possibilities (Milojević, 2010, 23). They include the following: concealing and the non -disclosure or incorrect disclosure of liabilities, including in the balance sheet those that should not be included, the overestimation or underestimation of liabilities, compensation with other positions in a prohibited way and a series of other actions. All of this enables the changing of the financial positions and the image of the earning ability of a company. Frauds are committed when forming liabilities are hard to detect. The fields and situations in which manipulations regarding liabilities can occur are the following ones:

When buying inventories, it is possible to manipulate liabilities emerging during this transaction. One of the methods is for a company not to show the liabilities that emerged during the purchase of different kinds of inventories or to show in its financial statements that those have been paid for. The American company Sirena Apparel Group Inc. inflated its sales revenue in 1999 with the aim of displaying the best trade results possible. At the same time, this company left out the record of the expenses having been made during the purchase and consequently the liabilities having emerged during the purchase 
of certain inventories. These manipulations created a seemingly better financial position of the company.

Accrued expenses (accrued liabilities) are expenses recognized as accrued and calculated, but which have not been paid yet. As a result, the unpaid sum is recorded as a liability in the balance sheet. The most frequent example of such accrued liabilities are calculated liabilities for salaries, taxes and contributions, various fees, rents, utility services, interest etc. If accrued liabilities are omitted or underestimated, it leads to an increase in the achieved result or to the underestimation of expenses from which those accrued liabilities have emerged. When, during the year 1998, General Electric Co. made its accrued expenses as a guarantee for the new turbines used for gas transport, the problem occurred when the design of the new turbine failed and the estimates showed that the expenses of the return or repair of the product would increase by around 100 million dollars more than what had been accrued and calculated previously. It was clear for them that it was inevitable to record a special sum which would increase the already accrued liabilities by the amount of the expenses of the guarantee in order to compensate for the potential receivable for the repair or cancellation of the turbines, so the company did not calculate the additional expenses and by this it performed a manipulation. A more radical example of using this method for the financial result manipulation is the company Centuri Inc. This company did not calculate the expenses of its employees' vacations, certain expenses related to tax and contributions, and the expenses of certain costs related to assets. All this resulted in the underestimation of the accrued liabilities in the amount of 912,672 dollars (Mulford \& Comiskey, 2002, 259);

The underestimation of liabilities is an equally „successful” instrument of fraud for stating bigger net assets and a bigger profit. Accounts payable, liabilities for employees, those based on accrued expenses, and those for the state, will be shown in a lower sum by omitting their recognition and the recognition of the expenses related to them (Škarić Jovanović, 2011, 221). Since, as a rule, accounts payable have the greatest share in overall current liabilities, and are strongly related to a change in the amount of inventories, a change of the relative relation between the growth of accounts payable and the growth of inventories is considered to be a good indication of a possible "financial numbers game" (Mulford \& Comiskey, 2002, 261);

One of the easiest ways to conceal liabilities is a conscious omission of their entry, i.e. the omission of liabilities. Perpetrators of this kind of frauds simply destroy, hide or put aside the documents on liabilities and related expenses; they do not record them in accounting books nor do they include them in financial statements (Petković, 2010, 232). Omissions in the recording of liabilities have the same purpose - without these, there are neither additional expenses nor a decrease in assets and a decrease in equity, which usually occurs (Singleton, Singleton, Bologna \& Lindquist, 2006, 110). A certain number of companies omit their liabilities on the basis of obtained loans. This is a radical move and it is very hard to conceal because every loan is seen both in the balance of the company which took it and in the balance of the company or bank which gave the loan. However, the justification of companies for not recording a loan is that the loan was taken by the owner as a natural person rather than by the company as a legal person or that there are technical issues on the part of the bank which did not provide the recording of the loan. Sometimes, certain companies do not record their liabilities for loans thinking that "no one will notice". The most frequent motive for concealing liabilities is the avoiding of showing the company's indebtedness in order to be granted new loans, deceive suppliers, attract investors and maintain the share prices on the capital market.

Cash - Cash - related frauds involve taking cash from the employer. The most frequent frauds of this type are: frauds related to stealing cash, frauds related to payment and the appropriation of a portion of cash.

Stealing cash - In order for a perpetrator to steal cash, he or she has to be in a position enabling him/her to have a direct contact with cash and the company's cash flows - the inflow and outflow of cash. The methods of stealing it can be assorted into two basic groups: the appropriation of cash "from the cash box" - this manipulation implies that cash is stolen directly from the box office of the company or from the fiscal 
cash register in a shop; the appropriation of cash "from deposit" - a company is obliged to pay all the money received from a sale or the provision of services in its current account at the end of the day. What happens is that individuals appropriate a portion of this money;

Frauds connected with paying in cash - This manipulation is hard to notice because the actions taken belong to the legitimate ways of payment. The problem is that certain parts of the transactions of charging and paying cash are fictional or unreal. The most frequent frauds related to payment in cash are: frauds related to invoicing - this manipulation involves using false invoices to take cash from a company; frauds related to the calculation of earnings - by using fictional employees, falsifying working hours, salaries and the sum of provision, by performing this kind of manipulation, cash goes out of a company in an illegal way; frauds related to the reimbursement of expenses - cash from a company is used for paying non-existing business expenses; and check frauds - the essence of this manipulation is falsifying checks either completely or only some parts of them (the sum, the issuer and the like);

The appropriation of a portion of cash - This manipulation appears in companies which do business with commerce, such as bars, restaurants, gas stations and retail stores. A good example would be the way Seigel Bugsy led transactions when he founded several casinos in Las Vegas. S. Bugsy needed to take the cash earned during a day or a week, appropriate one portion of it for the Chicago mafia and another for himself (non -taxable money) and register the rest as a revenue. If an owner, such as S. Bugsy, appropriates a certain amount from the cash which comes in and then records the rest in the accounting books, it is very hard to notice this kind of fraud. These frauds have the worst consequence on the state because of unpaid taxes. An example of this kind of fraud is the one known by the name of "Crazy Eddie", in which a family owning a company appropriated millions of dollars from retail stores selling electronics, leaving only as much as was necessary to show a minimal profit (Singleton, Singleton, Bologna \& Lindquist, 2006, 119).

\section{MANIPULATIONS IN CASH FLOW STATEMENTS}

A cash flow statement is a component of a regular annual set of financial statements in the practice of regular financial reporting. This statement enables an insight into a company's performance from a perspective completely different from balance sheets and income statements, by giving very detailed information on an inflow and an outflow within its business, financial and investing activities. In this way, cash flow statements function as the estimate of a company's exposure to financial risks. Frauds committed through financial statements are most often accomplished by manipulating the positions in balance sheets and income statements. This leads to information from cash flow statements being a valuable and very reliable informational resource for making business decisions. Information provided by a cash flow statement is safer because it is simpler to manipulate with revenues, expenses, assets and liabilities than with an inflow and an outflow of money. In general, there are two basic methods to manipulate operational activities in cash flow statements:

- Maximizing the inflow of money from operating activities - The inflow of money from operating activities should include an inflow from operating activities. However, companies may try to include inflows from the sale of assets in these. In the case of Enron, loans from banks were treated as inflows from operating activities. Although these items should be shown within the scope of financial activities, in cases like this, companies try to expand the definition of what falls into inflows from operating activities, on the one hand, and on the other, to narrow the scope of what falls into inflows from investment and financial activities. By displaying the biggest possible amount of inflows as inflows from operating activities, a company tends to show as good business results as they can be;

- Minimizing the outflow of money from operating activities - Companies applying this method perform a procedure opposite to the method of maximizing the inflow of money from operating activities. Companies tend to avoid showing 
as many outflows from operating activities as possible or transfer them to outflows from investment or financial activities by trying to narrow the definition of what falls into outflow from operating activities, on the one hand, and on the other, expand the scope of what falls into outflow from investment and financial activities. The reasons are the same as with the previous method: to show that a company is as successful as possible by reducing the outflow from its operating activities (Jones, 2011, 61).

According to certain theoreticians, there are four major methods of a cash flow manipulation, and these are (Schilit \& Perler, 2010, 190):

- Transferring an inflow from financial activities to an inflow from operating activities;

- $\quad$ Transferring outflows from operating activities to outflows from investing activities;

- Inflating cash flows from operating activities using acquisitions or selling a part of or the whole company;

- Increasing cash flows from operating activities using additional unsustainable activities.

Figure 2 is a presentation of the major methods of transferring an inflow to operating activities or an outflow from operating activities.

\section{Transferring an inflow from financial activities into an inflow from operating activities}

In certain situations, companies resort to various manipulations in order to display as much of an inflow from operating activities as possible. One of the methods enabling this is transferring an inflow from financial activities to an inflow from operating activities. The techniques of this type of fraud are as follows:

Recording fictitious inflows from operating activities on the basis of regular bank loans - This manipulation was accomplished in Delphi Corporation, a company from the USA which had problems during 2000 and was expelled from the General Motors Corporation a year earlier. The whole car industry within which Delphi Corporation operated had problems, so the management of this company tried in many ways to manipulate the results of the business in order to show the company's operation as successful as possible. During the year 2000, especially in the fourth quarter, the cash flows from operating activities were in the red. This was a big problem for Delphi Corporation because of the fact that exactly the inflow from operating activities was what was repeatedly emphasized as a sign of its successful operation. In December the same year, Delphi Corporation offered to sell inventories worth 200 million dollars to a bank (Bank One). The bank refused the offer, but Delphi Corporation offered

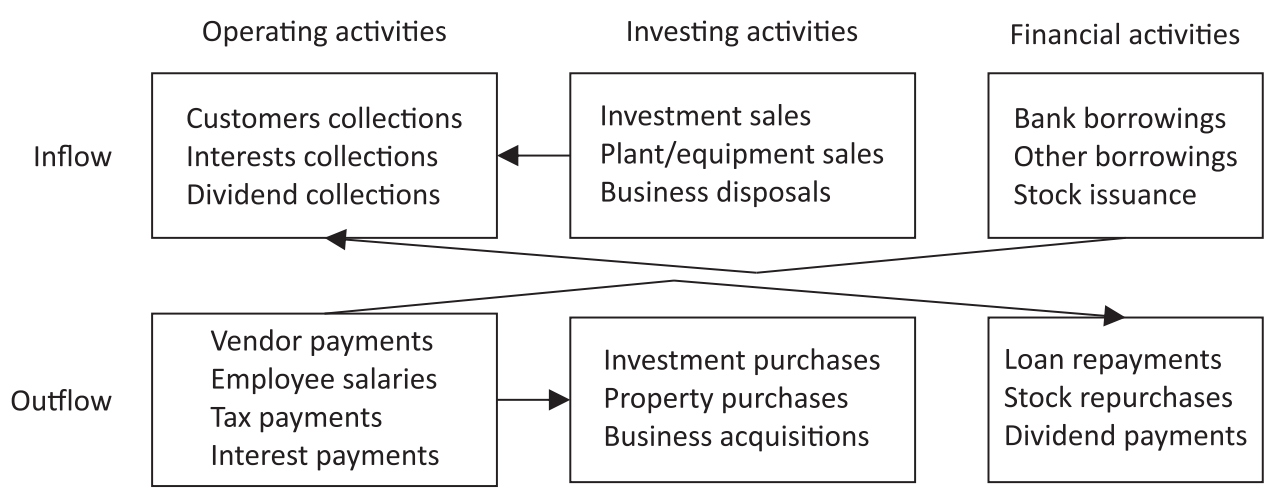

Figure 2 Cash flow frauds: „Robin Hoodd“ tricks 
the bank a possibility of buying out those inventories and "re-selling" them to the company in several weeks. In return, the Delphi Corporation would pay the bank certain compensation, depending on the sales value. Essentially, this was a classical short-term loan from the bank which, in the economic sense, demanded collateral (Delphi Corporation gave these inventories precisely as a guarantee). This loan was supposed to be shown as a bank loan and as an increase in the cash flows from financial activities. However, Delphi Corporation decided to show this loan as a classical sale of inventories to the bank in the amount of 200 million dollars. In the first place, this was a way to manipulate the inflow from sales, which was increased by 200 million dollars, and also falsely showed an increase in the inflow from operating activities on the basis of selling inventories. Using this manipulation in its cash flow statement from 2000, Delphi Corporation displayed a sum of 268 million dollars of the inflow from the operating activities, out of which sum only 68 million dollars were real (SEC Report, 2006). This is an example of the so -called double manipulation which many companies use. When a company increases its sales inflow artificially, such an inflow from operating activities is simultaneously increased. However, many auditors who discover the inflating of an inflow from sales neglect it, so this kind of manipulation often goes unnoticed.

Increasing the inflow from operating activities on the basis of selling receivables before the deadline - Companies often resort to selling their receivables as a useful strategy of improving their business results. From an economic standpoint, this is a very simple transaction: a company seeks an investor (most usually a bank) who wants to buy their receivables. In return, the company receives the money in the amount of those receivables reduced by the amount of a certain provision charged by the bank during the purchase. But there appears a question of how to interpret this transaction from the standpoint of cash flows. It is most frequently defined as an inflow from financial activities. However, companies very often define this inflow as the one originating from operating activities, due to the fact that they are most often receivables from sales. What needs to be taken into account is that the selling of such receivables can be performed in two ways: by the classical selling of receivables to a third party (most often a bank or some other financial organization), which is called factoring, or the selling of receivables to a third party (a financial organization) with the aim of buying a new financial instrument, i.e. some new securities, which is referred to as securitization. During 2004, the American pharmaceutical distributor Cardinal Health had problems with a lack of money and decided to sell a number of receivables. By the end of the year, Cardinal Health managed to gather over 800 million dollars by doing this. The sale represented the base for an increase in the inflow from operating activities during 2004 in the total sum of 971 million dollars in comparison with the previous year (from 548 million to 1.5 billion dollars). In this way, Cardinal Health transferred the inflow from operating activities from a future period (which it would have achieved by charging for the sold receivables) to the current one, thus creating the so -called "hole" in the future inflow of cash from operating activities (SEC Report, 2007). That is why it is very important that a sudden growth should be noticed during the conducting of an analysis of an inflow from operating activities, that not only the amount of such an increase but also the reason that led to the increase should be examined;

The inflating of an inflow from operating activities by charging for false receivables from customers - In order to display as good business results as possible, the American company Peregrine Systems decided to inflate their inflow by displaying a sale to non -existing buyers. By doing so, this company displayed not only a false inflow but also false receivables through which it had allegedly achieved that inflow. However, in addition to inflating the inflow from the false sale, Peregrine Systems did execute the sale of those non -existent receivables accounted for in the balance sheet. A bank bought those receivables, but the risk from charging, or non -charging, was taken by Peregrine Systems. From the economic standpoint, this is a classical bank loan because this money was given to Peregrine Systems by the bank, and the false receivables were taken from the bank as a guarantee; hence, this inflow was supposed to be shown as an inflow from financial activities rather than an inflow from selling receivables, i.e. as an inflow from operating activities (Ketz, 2004). 


\section{Transferring outflows from operating activities to outflows from investing activities}

A frequently used method of cash flow manipulation is transferring outflows from operating activities to outflows from investing activities with the aim of relieving cash flows from operating activities and showing the best business result possible. This method of manipulation can be achieved by applying the following techniques:

Inflating cash flows from operating activities with the so-called "boomerang" transactions - The American company Global Crossing dealt with building underwater optical cables intended to connect over 200 biggest cities in the world. However, since the project was approaching an end at the end of 2000 and at the beginning of 2001, doubts appeared considering whether Global Crossing would be able to cover the great expenses of the business and return the big loan taken. Global Crossing responded to these doubts by saying that there was no such problem and that one of the biggest indicators of their successful business was the big amount of the money at the company's disposal. Global Crossing had made many contracts beforehand, so it had received a large sum of money as an advance before the job was finished, which significantly increased the inflow from operating activities. During 2000, although Global Crossing had suffered a loss of 1.7 billion dollars, the cash flow statement showed positive cash flows from operating activities in the amount of 911 million dollars (Fabrikant \& Romero, 2002). This information appeased the investors. However, in a later analysis, it was noted that this high level of the inflow in cash was, on the one part, falsely shown through the so -called "boomerang" transactions. Since the majority of the companies dealing with telecommunications had problems at that time, Global Crossing agreed with the rest of them to make "boomerang" transactions to one another, which implied that Global Crossing would sell their products to other companies, but at the same time it would buy their products in the same amount. The influence of these transactions on the cash flow was such that Global Crossing showed the selling of these products as an outflow from investing activities, which relived cash flows from operating activities.
The inadequate capitalization of normal operational expenses - Performing the capitalization of operational expenses is one of the simplest operations by which expenses are decreased and business results are improved. However, many companies forget that by doing this, they burden cash flows, which can lead to a negatively shown cash flow. The famous example is WorldCom Company, which performed one of the biggest financial frauds in history. This company performed the capitalization of operational expenses in the amount of several billion dollars, but manipulated cash flows from operating activities at the same time. WorldCom showed the operational expenses as the purchasing of assets and therefore classified them in the cash flow statement as outflows from investing activities, rather than operating activities. In this way, WorldCom reclassified over 5 billion dollars of the cash outflow during 2000 and 2001 from business into investing activities (Beresford, Katzenbach \& Rogers, 2003);

\section{Inflating cash flows from operating activities by using acquisitions or selling a part of or the whole company}

Cash flow manipulations often occur when companies merge through acquisition or by selling a part of or the whole company. In this way, what happens is that they either solve the problem of a negatively displayed cash flow in a company undergoing merging or being sold, or a good base for a new merged company is set. The most widely used technique for this kind of fraud is the transfer of an outflow from operating activities to investing activities through an acquisition. By applying this manipulation in many cases during the purchase of a target company, the cash flows of that company, especially those from operating activities, are impressive; so, on that basis, investors come to the conclusion that companies work successfully. However, investigations often show that successful cash flows were the result of financial frauds. Every acquisition brings improvement of the cash flows of a company created by taking over another company. If a company is bought with cash, then that payment is recorded in outflows from investing activities. If it is paid in shares, there is no outflow of cash. The sole acquisition brings the acquiring company many other benefits. For 
example, every sale performed by the target company is recorded in the statements of the company which took over the other one as an inflow from sale, as well as an inflow from operating activities. However, the greatest chance for the improvement of cash flows through acquisition lies in the taken receivables and assets. These receivables and assets form certain expenses and outflows while being acquired, but all of that disappears before the acquisition. Then, after the acquisition, by charging these receivables and selling these assets, inflows are recorded in cash flow statements, which means that a company records an inflow from operating activities (by charging for receivables), but does not record outflows because they have occurred before the acquisition.

\section{An increase in cash flows from operating activities by using additional unsustainable activities}

In situations when they have problems with cash flows, many companies turn to the so -called unsustainable activities that help them overcome the existing problems. Unsustainable activities companies can use are numerous, but the most frequent ones are:

An increase in cash flows from operating activities by slowing the tempo of paying for liabilities - This is the easiest technique of a simple delay in paying for liabilities, especially towards suppliers, with the aim of manipulating cash flows. In this way, outflows from operating activities are delayed, most often for a period of one month. For instance, liabilities for December in the current year are delayed for January in the next year and in that way, the outflow of the current business year is decreased in the cash flow statement. However, it should be noted that this technique is typically not used for a longer period of time, because paying for liabilities cannot be delayed for an indefinite period of time. When Bob Nardelli was assigned the position of the top manager in the American company The Home Depot Inc. during 2000, great expectations were set before him. Nardelli found increasing cash flows from operating activities by decreasing the tempo of paying the accounts payable to be one of the ways for him to fulfill the investors' expectations. During 2001, Nardelli managed to prolong the payment deadline from 22 to 34 days, which brought the company a leap of cash flows from operating activities from 2.8 billion dollars to 6 billion dollars at the end of 2001. This big leap of cash flows is, on the one part, also accomplished by decreasing the tempo of buying inventories, which will later be discussed. During 2002, Nardelli kept trying to keep the high level of cash flows, primarily by prolonging the payment deadline. He partly succeeded in prolonging it from 34 to 41 days, but the cash flows from operating activities at the end of the year 2002 still fell from 6 billion to 4.8 billion dollars (Schilit \& Perler, 2010, 243);

An increase in cash flows from operating activities by accelerating the tempo of charging for receivables - With this technique, a company can improve its cash flow if there is a possibility for the company to convince its buyers in some way to pay their liabilities before the payment deadline. From the economic standpoint, larger charging of liabilities from customers is a good indicator. During 2002, through negotiations with its current customers, the American company EDS managed to obtain in advance 200 million dollars which they were supposed to take for the services to be given in the next two years. Still, EDS was not sincere towards its investors and failed to mention that the increase in the cash flows was the result of the accelerated charging of liabilities and that the tempo would not be maintained in the following period. The accelerated charging did lead to a sudden leap of the cash flows during 2002, but still it was the result of the short -term frauds with the aim of displaying a better image of the company's business. This example of a manipulation shows that it is a good, when the analysis of financial statements is carried out and the accelerated charging of accounts receivable is noticed. However, one should always be careful when coming to conclusions and thoroughly explore whether such accelerated charging is the result of successful business operations or a form of fraud.

An increase in cash flows from operating activities by decreasing the scope of buying inventories - The Home Depot Inc. company, as has already been said, managed to enlarge its cash flows in 2001 by turning to the prolonging of the deadline for the payment for liabilities. However, one part of the increase in the cash flow was also achieved by decreasing the scope of buying inventories. Quite simply, The Home Depot 
Inc. reduced the order from its suppliers by purchasing a smaller amount of inventories for every store than they had done before, i.e. the company did not buy the inventories in the same tempo as it had used to do in the previous period. With this technique, The Home Depot Inc. managed to decrease the outflow for buying inventories from 1.1 billion dollars during 2000 to even 166 million dollars during 2001 (Grow, 2007).

\section{METHODS OF FRAUD PREVENTION}

Detecting frauds is inevitably connected with preventing them and taken together these aspects secure the system of fraud control. For a successful prevention of frauds an adequate controlling environment needs to be established, the one in which all the employees, especially a company's manager, will adhere to certain ethical codes of behavior. The point is to stop all forms of fraud as well as the financial statement manipulations. The most important forms of fraud prevention are the following ones:

- The establishment and correct organization of internal control - Internal control represents a set of procedures or rules which serve to control a company's business operations. An efficient system of internal control implies, i.e. includes, a reliable accounting system, adequate control policies and the procedures and policies of securing the adequate protection of a company's assets. It also requires the clearly defined policies of accounting and financial reporting (Stefanović, 2000, 9). A company's management are responsible for establishing internal control. The most frequent forms of control used by internal control are: preventive control - focused on protecting the assets and the financial data of a company by trying to prevent frauds; detective control - tries to investigate into a fraud as soon as possible; corrective control - includes the activities intended to find a solution to the fraud detected in order to prevent future frauds;

- Creating fair business conditions - Fair conditions presume those in which employees follow ethical principles, where the aims of the company, rather than personal ones, are in the first place for the management, and in which employees' work is appreciated and respected. One of the first elements of creating these conditions is employing honest people. It is necessary that companies have a good system of checking their employees, especially new ones. A constant check of employees has shown in practice as an excellent way of checking employees (Albrecht \& Albrecht, 2004, 101). The second element contributing to creating fair business conditions is creating a positive working environment. For companies to be less sensitive to frauds, it is necessary that the system of "open doors" should be devised through a good corporate code of behavior, which would enable employees to have undisturbed communication, especially with senior managers, and to appoint positive and honest people to the key positions in the company;

- Providing employee training on dangers from frauds - Employees' awareness of what is considered to be an acceptable behavior and what is not should be developed amongst employees. The training of employees begins with the introduction of the term "fraud". The goal is for them to understand that preventing fraud is important for them as individuals as much as it is for the company as an entity. This training is important because many researches have shown that employees may be of key importance for detecting and preventing frauds, in terms of signaling and providing information on possible frauds.

- Establishing policies and procedures in a company - Internal control is established on certain policies and transactions which are deemed to be ethical are determined against the ones which are not. According to this, the fraud -related policy and carefully made accounting policies represent the base of the process of detecting and preventing business frauds.

- In addition to the previously stated general preventive measures, many companies use a number of other specific preventive measures. There are a large number of the measures that 
can be used in the process of business fraud prevention. The choice of a measure depends on many factors such as the size of a company, its financial possibilities, its personnel's qualifications, the characteristics of the company's business, the country where it operates, the system of internal control development, legal obligations etc. Only some of these measures will be mentioned here:

- Video surveillance - Surveillance mainly serves as a measure for detecting frauds, but it can also serve as a preventive measure for preventing frauds. It is important for video surveillance to be put in a visible spot, so that employees could be aware of the fact that every attempt they make to perform a fraud will be shot and seen.

- Constant supervision - Within this preventive measure, internal auditors and other kinds of control have the key role. Constant supervision does not leave individuals a possibility of committing a fraud. However, practice has shown that because of financial and human limitations constant supervision has to be performed in certain periods of time. There is a danger that fraudsters will be cautious in those periods and commit a fraud in periods deprived of such supervision;

- Legal proceedings taken against a fraudster can bring a great benefit to a company. It sends a strong message that if someone commits a fraud and is caught, the company will initiate legal proceedings and seek imprisonment for the perpetrators. Hence, legal proceedings may be considered as a preventive measure against future frauds in a company, because acting seriously as it does, the company shows future perpetrators that they should not take frauds lightly;

- Performing frequent and unannounced controls - In many companies, the exact time of the performance of regular controls is known and there is a danger that fraudsters will prepare themselves to conceal their frauds in many ways. For that particular reason, it is very important that frequent unannounced controls should be conducted. (Singleton, Singleton, Bologna \& Lindquist, 2006, 186)

\section{CONCLUSION}

The financial statements of a company are an important and inevitable source of information for investors and creditors in the process of making decisions on the allocation of assets; therefore, information which is clear, relevant and comparable needs to be contained in them. The tendency of managers to embellish the results of the business and the financial position of the company and to show its performances better than they really are lead to the financial statement manipulation, which can be marked as one of the main means of committing frauds. Many frauds in the previous period have led to the emergence of a large number of financial scandals which were the result of false financial reporting, which has led to a stricter and more detailed control of financial information.

A company's management is under constant pressure to achieve as good results as possible, especially in the conditions of a financial crisis. This pressure forces the management to resort to many forms of financial manipulation more frequently in order to show the expected business results. In addition to this pressure, many managers resort to financial frauds so as to achieve personal goals, get extra bonuses or avoid being fired. The techniques of creating fraudulent financial statements are manifold, and many items in such statements can be subject to manipulation (revenues, expenses, liabilities, assets, cash flows etc.). Still, practice has shown that revenues and expenses are most often the subjects of financial frauds. The reason for that is, before all, their significance for the analysis of a company's business as well as the existence of many techniques for manipulating the elements of financial statements. However, by analyzing a big number of frauds, it can be noticed that many fraudsters have manipulated the positions of balance sheets with the aim of influencing the result of the business and the financial position of the company in that way. The fact is that all forms of fraud ultimately leave a mark on indicators in balance sheets; in this paper, however, the manipulation techniques 
with a direct influence on the positions of balance sheets are emphasized.

It is precisely the analyses presented in the third part of this paper that point to the fact that manipulations of inventories, liabilities and cash are manipulation techniques most frequently used in balance sheets and that these manipulations have a long -term negative influence on the results of the business and the assets of a company. This proves the first hypothesis stated in this paper. The second hypothesis, saying that the techniques of the manipulation of an inflow and an outflow in cash flow statements are much harder to detect and prevent than other forms of manipulation, is proved by the analysis carried out in the fourth part of the paper.

Cash flow manipulations are much harder to commit, but also much harder to detect and prevent. The problem is that such manipulations are performed with real cash flows, unlike revenues and expenses yet to be collected. That is precisely the reason why manipulations with an inflow and an outflow are what only "experienced" fraudsters carry out. Practice has shown that perpetrators of these manipulations very skillfully conceal their traces and that the techniques used for committing them very often border with legal methods for showing the cash flows of a company. That is why it is very hard to detect this mode of manipulation and when analyzing these frauds, it is necessary that a company's business operations should much more thoroughly be analyzed in order to notice the interconnectedness of the positions in different financial statements and use various techniques of detecting frauds in the right way in order to prevent this kind of manipulation in future and regain trust in the information presented in financial statements.

Analyzing manipulations in balance sheets and cash flow statements and pointing to a need for a more serious control of the elements of these reports are the biggest contributions of this paper. The problem is that all forms of control pay the most attention to the analysis of manipulations of revenues and expenses and by that fail to notice manipulations perpetrated in balance sheets and cash flow statements. All these statements are interconnected and a manipulation performed in one statement either directly or indirectly influences all the others. By analyzing the techniques of the manipulation of inventories, liabilities, cash, an inflow and an outflow, the problem of their detection and simultaneously their prevention is pointed out.

\section{REFERENCES}

Albrecht, S., \& Albrecht, C. (2004). Fraud Examination and Prevention. Ohio: USA, Thomson-South-Western.

Beresford, D., Katzenbach, N., \& Rogers, C. (2003). Report of Investigation of the Board of directors of Worldcom. INC. retrived 20.05.2015, from http://www.sec.gov/Archives/edgar/ data/723527/000093176303001862/dex991.htm.

Grow, B. (2007). Out a Home Depot. retrived 21.05.2015, from http://www.bloomberg.com/bw/stories/2007-01-04/out-athome-depotbusinessweek-business-news-stock-marketand-financial-advice.

Dmitrović Šaponja, Lj., Milutinović, S. i Šijan, G. (2007, maj). Zloupotrebe u računovodstou - rizik objektionog finansijskog izveštavanja. Rad prezentiran na XII međunarodnom naučnom skupu SM 2007 Strategijski menadžment i sistemi podrške odlučivanju u strategijskom menadžmentu, Subotica, Republika Srbija: Ekonomski fakultet u Subotici Univerzitet u Novom Sadu.

Fabrikant, G., \& Romero, S. (2002). How Executives Prospered as Global Crossing Collapsed. retrived 15.05.2015, from http:// www.nytimes.com/2002/02/11/business/how-executivesprospered-as-global-crossing-collapsed.html.

Jakšić, D. i Vuković, B. (2012). Uticaj krize na manipulisanje finansijskim izveštajima. Rad prezentiran na 16. kongresu Saveza računovođa i revizora Republike Srpske. Banja Vrućica: Republika Srpska.

Jones, M. (2011). Creative Accounting, Fraud and International Accounting Scandals. London, England: John Wiley \& Sons.

Ketz, E. (2004). The Accounting CyclePeregrine Systems - Or the Lack of Them. retrived 15.05.2015, from http://accounting. smartpros.com/x46099.xml.

Malinić, D. (2009a). Prepoznavanje bilansnih rizika. Ekonomija preduzeća - Tajne bilansa: Menadžerski pristup. Beograd.

Malinić, D. (2009b). Cash-flow kao instrument otkrivanja poslovnofinansijskog rizika. Zbornik radova XL Simpozijuma 40 godina Računovodstva i Poslovnih finansija - dometi i perspektive, Beograd: Republika Srbija, Savez računovođa i revizora Srbije, 57-60. 
Međunarodni standardi i saopštenja revizije. (2005). Beograd, Republika Srbija: Savez računovođa i revizora Srbije.

Milojević, M. (2009). Motivi i uslovi za finansijske prevare. Revizor, 46, 41-48.

Milojević, M. (2010). O rizicima finansijskog izveštavanja. Revizor, 52, 7-25.

Mulford, C., \& Comiskey E. (2002). The Financial Numbers Game, New York, NY: John Wiley \& Sons.

Petković, A. (2010). Forenzička revizija - Kriminalne radnje u finansijskim izveštajima, Novi Sad, Republika Srbija: Proleter A.D. Bečej.

Petrova, D. (2008). Korišćenje računovodstvenih procena u manipulativnom finansijskom izveštavanju i odgovornosti revizora. Računovodstvo, 7-8, 23-34.

Schilit, H., \& Perler, J. (2010). Financial shenanigans - How to detect accounting gimmicks $\&$ fraud in financial reports (third edition). New York, NY: McGraw-Hill.

SEC Report. (2006). Charges Delphi Corporation and Nine Individuals, Including Former CEO, CFO, Treasurer and Controller, in Wide-Ranging Financial Fraud; Four Others Charged With Aiding and Abetting Related Violations, retrived 20.05.2015, from http://www.sec.gov/news/press/2006/2006-183.htm.
SEC Report. (2007). SEC Sues Cardinal Health, Inc. For Fraudulent Earnings and Revenue Management Scheme, retrived 20.05.2015, from http://www.sec.gov/news/press/2007/2007-147.htm.

Singleton, T., Singleton, A., Bologna, J., \& Lindquist, R. (2006). Fraud auditing and Forensic Accounting. New York, NY: Johne Wiley \& Sons.

Stančić, P., Dimitrijević, D. i Stančić, V. (2013). Forenzičko računovodstvo - odgovor profesije na prevare $\mathrm{u}$ finansijskim izveštajima. Teme, 4, 1879-1897.

Stefanović, R. (2000). Sprečavanje i otkrivanje lažnog finansijskog izveštavanja. Računovodstvo, 11, 3-11.

Radulović, B. (2010). Procenjivanje i rizici finansijskog izveštavanja. Revizor, 52, 27-45.

Škarić Jovanović, K. (2011). Finansijski izveštaji kao instrument prevare. Rad prezentiran na VI kongresu računovođa i revizora Crne Gore.

Urošević, N. (2010). Neistiniti finansijski izveštaji - kome služe. Privredni savetnik, 5, 50-59.

Wells, J. (2005). Principles of Fraud Examination. New York: NY, John Wiley \& Sons.

Zabihollah, R. (2002). Financial Statement Fraud - Prevention and Detection. New York, NY: John Wiley \& Sons.

Received on $12^{\text {th }}$ June 2015, after revision, accepted for publication on $17^{\text {th }}$ August 2015. Published online on $25^{\text {th }}$ August 2015

Dragomir Dimitrijevic is an Assistant Professor at the Faculty of Economics of the University of Kragujevac, where he has received his PhD in the narrow scientific field of Accounting, Auditing and Business Finance. In the undergraduate and master studies of the Faculty, he teaches the subjects of Financial Accounting and Forensic Accounting. The areas of his scientific interest are Financial Reporting, Frauds in Business and Forensic Accounting 


\title{
OTKRIVANJE I SPREČAVANJE MANIPULACIJA U BILANSU STANJA I IZVEŠTAJU O NOVČANIM TOKOVIMA
}

\author{
Dragomir Dimitrijević* \\ Ekonomski fakultet Univerziteta u Kragujevcu
}

Finansijski izveštaji koji sadrže objektivne, realne i pouzdane informacije predstavljaju ključnu osnovu za donošenje mnogobrojnih poslovnih odluka. Ukoliko se pri sastavljanju finansijskih izveštaja koriste određene manipulativne tehnike radi prikazivanja što boljih rezultata poslovanja, kvalitet finansijskih izveštaja će biti ugrožen. Mnogobrojne finansijske prevare dovele su do velikog nepoverenja u sistem finansijskog izveštavanja i računovodstveno-revizorsku profesiju, koji su neretko optuživani za nastanak prevara i gubljenje poverenja u pouzdanost finansijskih informacija od strane brojnih korisnika i donosilaca ekonomskih odluka. Iz tih razloga, u ovom radu su razmatrane tehnike manipulacija u finansijskim izveštajima, posebno, u bilansu stanja i izveštaju o novčanim tokovima, jer se ovi oblici manipulacija teže otkrivaju i sprečavaju u odnosu na manipulacije prihodima i rashodima u bilansu uspeha.

Ključne reči: bilans stanja, izveštaj o novčanim tokovima, finansijsko izveštavanje, prevare, tehnike manipulacija

JEL Classification: M48, K42

\section{UVOD}

Prevare u poslovanju preduzeća su najčešće povezane sa manipulacijama pozicija u finansijskim izveštajima. Veliki finansijski skandali koji su se pojavili početkom XXI veka - Enron, Worldcom (Stančić, Dimitrijević i Stančić, 2013, 1895) doveli su do gubitaka u vrednosti od nekoliko milijardi dolara. Ove gubitke su snosili ne samo vlasnici i poverioci kompanija u kojima su prevare ostvarene, već i mnogobrojne privrede širom sveta u

\footnotetext{
* Korespondencija: D. Dimitrijevic, Ekonomski fakultet Univerziteta u Kragujevcu, Đ. Pucara 3, 34000 Kragujevac, Republika Srbija; e-mail: dimitrijevicd@kg.ac.rs
}

kojima su ove kompanije poslovale. Manipulativni finansijski izveštaji se sastavljaju sa ciljem prikazivanja lažnog finansijskog položaja, uspešnosti i novčanih tokova preduzeća. Najveću odgovornost za sastavljanje i prezentovanje manipulativnih finansijskih izveštaja snosi menadžment preduzeća. Najčešće opravdanje menadžmenta za ostvarivanje prevara jeste da su na taj način pokušali da spasu preduzeće i osiguraju dobit za vlasnike preduzeća. Najčešći oblici manipulacija su "naduvavanje" prihoda, smanjivanje rashoda, povećanje ili lažiranje potraživanja, smanjivanje ili neprikazivanje obaveza, uvećanje vrednosti zaliha, lažiranje priliva i odliva novca iz preduzeća. Ovo su samo neki od oblika manipulacija $u$ finansijskim 
izveštajima, kojima menadžment želi da prikaže što bolje rezultate poslovanja. Međutim, mnogobrojni primeri finansijskih prevara su ukazali da se iza ovih manipulacija krije želja menadžmenta da ostvari lične ciljeve, kao što su ostvarivanje dodatnih bonusa koji su vezani za rezultat poslovanja, želja za dodatnim bogatstvom, osiguranje posla, pohlepa pojedinca, želja da se živi boljim životnim standardom nego što sopstvene finansijske mogućnosti to dozvoljavaju, postojanje ličnih dugova, slaba kreditna sposobnost, lični finansijski gubici i slično.

Analizirajući mnogobrojne slučajeve prevara $u$ kompanijama koje su ostvarene sastavljanjem manipulativnih finansijskih izveštaja, uočava se da su najčešće korišćene tehnike manipulacija bile prevare vezane za prihode $\mathrm{i}$ rashode $\mathrm{u}$ bilansu uspeha. Manipulacije rashodima i prihodima su ,jednostavnije“ za počinioce kriminalnih dela, jer postoji veliki broj tehnika za manipulacije; na ovaj način se direktno, i u kratkom periodu, utiče na finansijski rezultat preduzeća i, samim tim, brže i lakše ispunjavaju lični ciljevi menadžmenta. Međutim, pošto su prihodi i rashodi u bilansu uspeha najćešće "meta" počinilaca prevara, mnogobrojni organi kontrole (interna i eksterna revizija, državni organi i forenzičke računovođe) raspolažu velikim brojem tehnika uz pomoć kojih otkrivaju i sprečavaju manipulacije prihodima i rashodima. S druge strane, pozicije ostalih finansijskih izveštaja, posebno bilansa stanja i izveštaja o novčanim tokovima, su, takođe, predmet manipulacija. Ipak, praksa je pokazala da su ove manipulacije ređe $u$ odnosu na manipulacije $u$ bilansu uspeha. To ne znači da se one ne primenjuju, već znači da se teže otkrivaju, i da ovim manipulacijama pribegavaju samo oni počinioci prevara koji su u stanju da vešto prikriju tragove prevara.

Upravo su tehnike otkrivanja i sprečavanja manipulacija u bilansu stanja i izveštaju o novčanim tokovima predmet analize $\mathrm{u}$ ovom radu. Sve pozicije $\mathrm{u}$ bilansu stanja mogu biti predmet manipulacije. Ipak, pokazalo se da su zalihe, gotovina i obaveze najčešće predmet manipulacija. $S$ druge strane, svim prilivima i odlivima novca, koji se prikazuju u izveštaju o novčanim tokovima, može se manipulisati, ali praksa je pokazala da su uvećavanje priliva i smanjivanje odliva po osnovu poslovnih aktivnosti $u$ večini slučajeva najčešće tehnike manipulacije u ovom izveštaju.

Cilj istraživanja $u$ ovom radu jeste identifikovanje mogućnosti i instrumenata za sprečavanje i otkrivanje manipulacija u bilansu stanja i izveštaju o novčanim tokovima. Mora se imati $u$ vidu da svaka manipulacija prihodima i rashodima u bilansu uspeha direktno ili indirektno utiče i na imovinu, kapital i obaveze, i na prilive i odlive novca. Međutim, $u$ ovom radu se ukazuje na tehnike manipulacija koje direktno utiču na pozicije bilansa stanja i izveštaja o novčanim tokovima, sa ciljem da se na taj način prikaže što bolji rezultat poslovanja i povoljnija finansijska situacija $u$ preduzeću.

U skladu sa postavljenim predmetom i ciljem istraživanja, u radu se polazi od sledećih hipoteza:

H1: Najčešće korišćene manipulacije u bilansu stanja, kojima se direktno utiče na rezultat poslovanja i finansijsku poziciju preduzeća, su manipulacije zalihama, obavezama i gotovinom.

H2: Tehnike manipulacija priliva i odliva novca u izveštaju o novčanim tokovima se teže otkrivaju i sprečavaju od ostalih oblika manipulacija.

Postavljene hipoteze biće testirane primenom kvalitativne metodologije istraživanja zasnovane na deskriptivnoj analizi. Polazeći od relevantne literature koja sadrži teorijska razmatranja, i od analize konkretnih slučajeva, izvešće se opšti zaključci o razmatranom problemu. Od posebnog značaja biće metoda indukcije, kojom će se, polazeći od konkretnih primera manipulacija, izvući opšti zaključak o svim tehnikama manipulacija koje se koriste $\mathrm{u}$ bilansu stanja i izveštaju o novčanim tokovima. Samim tim, analizirajući već primenjivane tehnike manipulacija, želi se ukazati na mogućnost jednostavnijeg i bržeg otkrivanja i sprečavanja ovakvih i sličnih oblika manipulacija u budućnosti.

Rad je strukturiran u šest delova. Nakon uvodnih razmatranja, $\mathrm{u}$ drugom delu daje se pregled literature o pojmu, značaju i tehnikama manipulacija u finansijskim izveštajima. Treći deo razmatra tehnike manipulacija u bilansu stanja, ali se posebno analiziraju tehnike manipulisanja zaliha, obaveza i 
gotovine. Najćešće metode manipulacija prilivima i odlivima novca u izveštaju o novčanim tokovima su predmet analize $u$ četvrtom delu. Detaljno se analiziraju tehnike manipulisanja prilivima i odlivima iz poslovnih aktivnosti preduzeća. Peti deo rada analizira metode sprečavanja svih oblika prevara, pa samim tim i prevare $u$ finansijskim izveštajima. Na kraju, prezentovani su stavovi o ispunjenosti hipoteza i ukazano je na doprinos rada.

\section{TEORIJSKI ASPEKTI}

Sistem finansijskog izveštavanja predstavlja jedini potpuni kvantitativni sistem koji obuhvata sve poslovne transakcije koje se dešavaju unutar preduzeća, kao i transakcije sa pojedincima, preduzećima i institucijama u okruženju (Malinić, 2009a, 139). Finansijsko izveštavanje je isključiva odgovornost menadžmenta i moćan instrumenat upravo za razna prilagođavanja radi prikazivanja slike o poslovnom subjektu boljom nego što ona jeste. Ovo sve u cilju privlačenja potencijalnih investitora, lakšeg dobijanja povoljnijih kredita, rasta cena akcija na berzi i slično (Dmitrović Šaponja, Milutinović i Šijan, 2007). "Menjanje bilansa stanja”, „upravljanje dobitkom”, "friziranje računa" su termini koji se koriste za objašnjavanje postupaka usmerenih ka manipulaciji finansijskim izveštajima, radi ostvarivanja određenih ciljeva. Oni mogu obuhvatati širok spektar zakonitih i nezakonitih upravljačkih postupaka (Petrova, 2008, 24). Finansijske pronevere su fenomen koji ima svoje motive, a tlo za razorno dejstvo im je tim povoljnije što je finansijsko izveštajno okruženje slabije organizovano (Milojević, 2009, 41).

Brojne finansijske prevare i skandali s kraja XX i početkom XXI veka, kao i pojava globalne finansijske i ekonomske krize, istakli su u prvi plan neophodnost da finansijsko-računovodstvene informacije poseduju određene glavne karakteristike: razumljivost, relevantnost, pouzdanost, uporedivost i konzistentnost (Radulović, 2010, 27). Manipulacije u finansijskim izveštajima mogu da uzdrmaju i najrazvijenija tržišta kapitala i dovedu do manje ili veće finansijske krize i poremećaja u njihovom funkcionisanju. Lažni finansijski izveštaji postoje od kada postoji finansijsko izveštavanje, jer se njima postižu određeni kratkoročni materijalni ciljevi menadžmenta ili vlasnika. Oni su prisutni ne samo u tranzicionim zemljama, već i u zemljama sa razvijenim privredama i razvijenim sistemima finansijskog izveštavanja. Osnovni cilj manipulativnog finansijskog izveštavanja je da se prikazivanjem pogrešne slike o finansijskom položaju preduzeća i njegovoj profitabilnosti stekne korist za počinioce, a neki od korisnika finansijskih izveštaja (kreditori, investitori) su u ovom obliku kriminalne radnje oštećena strana koja preuzima rizik od gubitka finansijskih sredstava time što će biti navedena da donese pogrešne odluke (Jakšić i Vuković, 2012, 414).

Prema međunarodnim standardima revizije, lažno finansijsko izveštavanje predstavlja kriminalnu radnju koju karakteriše namerno pogrešno iskazivanje ili izostavljanje određenih podataka ili obelodanjivanja u finansijskim izveštajima (Međunarodni standardi i saopštenja revizije, 2005, 277). Udruženje ovlašćenih istražitelja prevara (ACFE) definiše lažno finansijsko izveštavanje kao „namerno lažno prikazivanje materijalnih činjenica ili računovodstvenih podataka koje vodi do toga da korisnik finansijskih informacija, koje su prezentovane $\mathrm{u}$ okviru finansijskih izveštaja, donese pogrešne odluke" (Zabihollah, 2002, 2). Američki institut ovlašćenih javnih računovođa (AICPA) definiše lažno finansijsko izveštavanje kao „namerne netačnosti ili izostavljanje iznosa ili obelodanjivanja u finansijskim izveštajima, da bi se obmanuli korisnici finansijskih izveštaja“. Ono može da uključuje (Stefanović, 2000, 4):

- manipulaciju, falsifikovanje ili prepravku računovodstvene evidencije ili pratećih dokumenata, koji se koriste u pripremi finansijskih izveštaja;

- netačna (lažna) predstavljanja ili namerna izostavljanja značajnih događaja ili transakcija iz finansijskih izveštaja;

- namerno pogrešnu primenu računovodstvenih pravila.

Prevare $\mathrm{u}$ finansijskim izveštajima mogu nastati putem (Wells, 2005, 324): 
- falsifikovanja materijalnih činjenica, dokumenata ili poslovnih transakcija;

- lažnim prikazivanjem događaja, transakcija, računa ili ostalih značajnih informacija na osnovu kojih nastaju finansijski izveštaji;

- namernim pogrešnim korišćenjem računovodstvenih načela, politika ili procedura koje se koriste za vrednovanje, priznavanje i evidentiranje poslovnih transakcija;

- lažnom prezentacijom finansijskih informacija u okviru finansijskih izveštaja.

\section{MANIPULACIJE U BILANSU STANJA}

Najčešći oblici malverzacija koji se javljaju u preduzećima, a povezani su sa kategorijama $u$ bilansu stanja, su precenjivanje potraživanja, manipulacije zalihama materijala, robe i gotovih proizvoda, precenjivanje i potcenjivanje obaveza, izostanak evidencije obaveza, itd. Manipulacije izvršene u bilansu stanja su direktno ili indirektno povezane sa manipulacijama prihodima i rashodima u bilansu uspeha i sa novčanim tokovima u izveštaju o novčanim tokovima. Drugim rečima, nemoguće je manipulisati pojedinim elementima iz bilansa stanja, a da se time ne utiče na rashode i prihode. Ukoliko počinilac prevare želi da sakrije svoje kriminalne radnje potrebno je da "prikrije” tragove manipulacija u svim finansijskim izveštajima u kojima ta prevara ima uticaj. Na primer, ukoliko se izostavlja određena obaveza prema dobavljačima, to utiče i na smanjivanje budućih rashoda i odliva gotovine koji bi se javili pri plaćanju tih obaveza. Međutim, ta prikrivena obaveza je rezultirala povećanjem određenog dela imovine, koje se, takođe, mora izostaviti iz bilansa. To ukazuje da su prevare u bilansu stanja veoma složene, tako da ih je teško otkriti, ukoliko su počinioci uspešno sakrili sve dokaze ostvarene prevare.

Kada je reč o materijalnoj i nematerijalnoj imovini, uticaj na njenu vrednost se od strane menadžmenta i računovođa, najčešće, realizuje putem nepravilne primene, ili, preciznije, zloupotrebe pravila za aktiviranje izdataka izvršenih $u$ vezi sa ovom imovinom i putem precenjivanja, odnosno, potcenjivanja rezidualne vrednosti sredstava, njihovog veka trajanja i izbora metoda otpisivanja. U okviru MRS 16 - Nepokretnosti, postrojenja i oprema, MRS 38 - Nematerijalna ulaganja, MRS 23 - Troškovi pozajmljivanja, MSFI 3 - Poslovne kombinacije dati su zahtevi za aktiviranjem izdataka povezanih sa materijalnim ili nematerijalnim ulaganjima od kojih se u budućnosti očekuje priliv ekonomskih koristi. Drugim rečima, kapitalizacija, sama po sebi, ne predstavlja instrument za ostvarivanje prevara $\mathrm{u}$ finansijskim izveštajima. Aktiviranje naknadnih ulaganja u osnovna sredstva, troškovi kamata, ulaganja u troškove razvoja, kao najčešći izdaci koji se kapitalizuju, postaju instrument prevara ako nisu ispunjeni standardima propisani uslovi za kapitalizaciju (Škarić Jovanović, 2011, 218). Prethodno navedene mogućnosti uticaja na rezultat i kapital preduzeća, precenjivanjem imovine i potcenjivanjem obaveza, potencijalno su uzrok manjeg ili većeg narušavanja iskazne moći bilansa. Problem je u tome što ovakvo ponašanje stvara skrivene gubitke, i što bilansi opterećeni skrivenim gubicima, preko nerealne predstave o stvarnoj zarađivačkoj i finansijskoj poziciji preduzeća, upućuju investitore na pogrešne odluke. Objektivizacija visokih skrivenih gubitaka često znači i kraj za kompaniju (Malinić, 2009b, 58).

Tipični primeri precenjivanja imovine i potcenjivanja obaveza predstavljeni su na Slici 1.

Zalihe su bitan element uspešnosti poslovanja preduzeća. Od pravilnog i efikasnog upravljanja zalihama zavisi i uspeh poslovanja preduzeća. Preciznije, ukoliko preduzeće nabavlja potreban nivo zaliha i ne blokira svoj novac u njima, to će dovesti do boljih rezultata poslovanja, pod ostalim jednakim uslovima. Takođe, brojne finansijske institucije su davanje kredita mnogim preduzećima uslovile uzimanjem zaloge na zalihama, pa samim tim su zainteresovane za kretanje zaliha i njihov uticaj na rezultat poslovanja. Ako se razmatraju prevare u vezi svih oblika zaliha, onda se može reći da se nelegalno prisvajanje zaliha može izvršiti putem:

formiranja lažnih trebovanja - Lažnim trebovanjima počinilac prevare povlači sa zaliha veće 


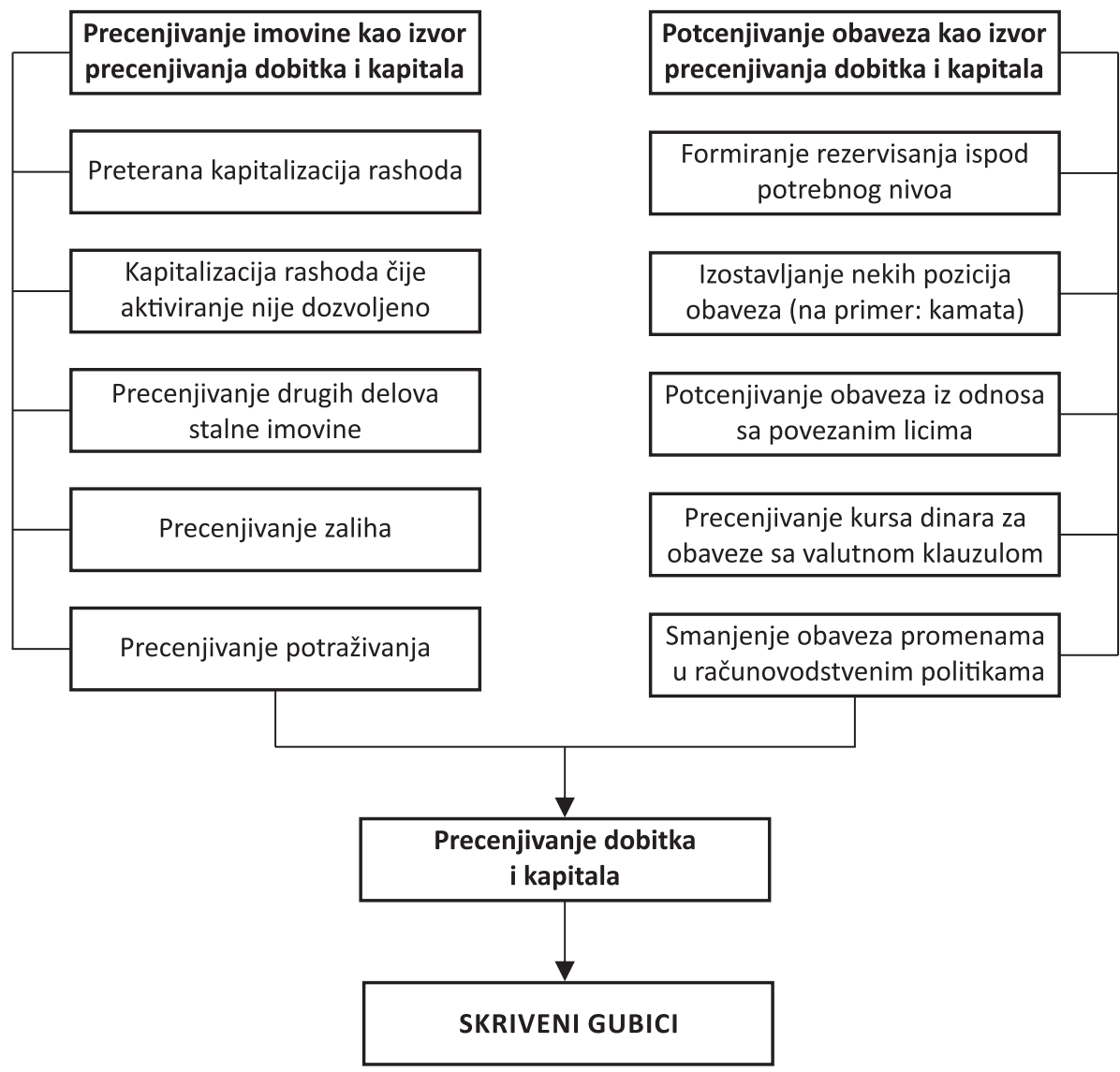

Slika 1 Precenjivanje imovine i potcenjivanje obaveza kao izvori nerealnog povećanja dobitka i kapitala

Izvor: Malinić, 2009b, 57

količine nego što je potrebno, sa ciljem da taj višak zadrži ili proda na "crno“;

ostvarivanja fiktione prodaje - Formiraju se lažne fakture koje se obično adresiraju fantomskim firmama ili firmama saučesnicama u prevari. Ovom manipulacijom rešava se istovremeno i problem manjka zaliha, ali i „naduvavanja“ prihoda od prodaje nastalih lažnim fakturama;

nelegalnog prisvajanja prilikom kupovine $i$ prijema zaliha - Prilikom kupovine i prijema zaliha počinilac prevare svesno zadržava jedan deo tih zaliha. Da bi se prekrila ova manipulacija najčešće se formira falsifikovana dokumentacija prilikom prijema kupljenih zaliha. Jedan od mogućih načina izvršenja ovog oblika prevare je kada osoba zadužena za prijem kupljene materijalne imovine falsifikuje prijemne dokumente u kojima prikazuje da je umesto, na primer, stvarnih 1.000 jedinica robe, od dobavljača prispelo samo 900, i samim tim ostalih 100 jedinica prisvaja za sebe. Očigledan problem u ovom slučaju je da prijemni dokumenat neće odgovarati fakturi dobavljača, pa će nastupiti problem u plaćanju. U ovom primeru, ako faktura dobavljača glasi na 1.000 jedinica robe, a prijemni dokumenat ukazuje na prijem 900 jedinica, neko će morati da objasni kako nedostaje 100 jedinica. Problem za počinica je što dobavljač može ukazati da je isporuka u potpunosti izvršena. U ovom slučaju, počinilac u određenim uslovima može izbeći problem izmenom samojednog primerka prijemnog dokumenta. Kopija dokumenta koja se šalje računovodstvu ukazala 
bi na prijem pune isporuke robe, tako da bi dobavljač bio isplaćen u potpunosti, ali bi kopija primerka koji se dostavlja za robno knjigovodstvo mogla biti lažna i umanjena za prisvojeni iznos. Time bi stvarno stanje robe $\mathrm{u}$ magacinu odgovaralo dokumentima robnog knjigovodstva. Ovo je jednostavan primer prevare koja se može izvršiti samo u preduzećima koja imaju slabe interne kontrole, i kod nabavke robe koje su pojedinačno izuzetno skupe, ali lako unovčljive (Petković, 2010, 213);

vrednovanja zaliha materijala - Najčešće korišćena manipulacija je učestalo menjanje metode obračuna izlazne vrednosti zaliha, jer se čestim menjanjem ovih metoda prikazuju različiti efekti $\mathrm{u}$ bilansu uspeha. Ovde se, pre svega, misli na situaciju kada preduzeće u kratkim rokovima menja računovodstvene politike obračuna izlaza zaliha. Na primer, $\mathrm{u}$ prethodnoj godini je za istu vrstu zaliha preduzeće primenilo FIFO model kod obračuna izlaza, a već naredne godine primenjuje metod ponderisanog prosečnog troška. MRS 2 dozvoljava primenu oba metoda, ali to ne znači da ih treba za istu vrstu zaliha primenjivati naizmenično, jednu pa drugu. FIFO metoda podrazumeva da se izlaz zaliha obračunava tako što se kod prvog izlaza uzima prva ulazna cena i tako redom, dok se kod metode prosečno ponderisanih troškova, kod svakog izlaza uzima cena koja se dobija kao umnožak količine i cene konkretne vrste zaliha koje su prethodile izlazu (Urošević, 2010, 54).

Obaveze su neminovnost svakog preduzeća. Sposobnost preduzeća da svoje obaveze servisira na vreme ukazuje na zdravu finansijsku poziciju preduzeća. $\mathrm{S}$ druge strane problemi $\mathrm{u}$ izmirenju obaveza ukazuju na probleme u poslovanju preduzeća. Neke obaveze podrazumevaju, svojim nastankom, promene samo $u$ okviru bilansa stanja, što znači da nastaje povećanje imovine. U drugom slučaju, obaveze nastaju uz istovremeni nastanak rashoda, što znači da se ove promene prenose i na bilans stanja i na bilans uspeha. Podložnost prevarama u vezi sa obavezama je tim veća ako se operacije vezane za prevare mogu preneti i na bilans stanja i na bilans uspeha. Različite obaveze daju različite mogućnosti za manipulisanje (Milojević, 2010, 23). U pitanju su: skrivanja i neobelodanjivanja, ili pogrešna obelodanjivanja obaveza, ubacivanja u bilans obaveza koje to nisu, precenjivanje ili potcenjivanje obaveza, prebijanje sa drugim pozicijama kako to nije dozvoljeno i niz drugih radnji. Sve ovo omogućava da se menja finansijska pozicija i predstava o zarađivačkoj sposobnosti preduzeća. Prevare koje nastaju pri formiranju obaveza se teško otkrivaju. Oblasti i situacije u kojima se mogu javiti manipulacije sa obavezama su sledeće:

Prilikom kupovine zaliha mogućeje manipulisati obavezama koje nastaju pri ovoj transakciji. Jedna od metoda je da preduzeća ne prikazuju obaveze nastale pri kupovini različitih oblika zaliha, ili u svojim finansijskim izveštajima prikažu da su te obaveze plaćene. Američko preduzeće Sirena Apparel Group Inc. je tokom 1999. godine naduvalo svoje prihode od prodaje, sa ciljem prikazivanja što boljeg rezultata poslovanja. Istovremeno je ovo preduzeće izostavilo evidenciju troškova nastalih prilikom prodaje, ali samim tim i obaveze koje su nastale prilikom kupovine određenih zaliha. Ove manipulacije su stvorile prividno bolju finansijsku poziciju preduzeća;

Razgraničeni obračunati troškovi (obračunate obaveze) su troškovi koji su prepoznati kao razgraničeni i obračunati ali još uvek nisu plaćeni. Kao rezultat toga neplaćeni iznos se evidentira kao obaveza u bilansu stanja. Najčešći primeri obračunatih obaveza su obračunate obaveze po osnovu zarada, poreza i doprinosa na zarade, raznih taksi, rente, komunalnih usluga, kamata, itd. Ukoliko se obračunate obaveze izostave ili se potceni njihov iznos, to dovodi do povećanja ostvarenog rezultata, ili potcenjivanja rashoda na osnovu kojih su te obračunate obaveze i nastale. Kada je tokom 1998. godine, General Electric Co. izvršila razgraničenje troškova garancija za nove turbine, koje su se koristile za prenos gasa, problem je nastao kada je dizajn nove turbine propao, i kada su procene ukazivale da će troškovi povraćaja ili popravke proizvoda biti viši za oko 100 miliona dolara nego što je bio iznos troškova koji je razgraničen i obračunat. Kompaniji je postalo jasno da je neophodno da evidentira poseban iznos kojim bi povećala već obračunate obaveze po osnovu troškova garancije, kako bi nadoknadila potencijalna potraživanja po osnovu popravke ili opoziva turbina, pa kompanija nije obračunala dodatne troškove i time izvršila 
manipulaciju. Još radikalniji primer korišćenja ove metode za manipulaciju finansijskog rezultata je primer kompanije Centuri Inc. Ova kompanija nije obračunala troškove godišnjih odmora zaposlenih, određene troškove zaposlenih po osnovu poreza i doprinosa i troškove pojedinih taksi po osnovu imovine. Rezultat toga je bilo potcenjivanje obračunatih obaveza $u$ iznosu od 912.672 dolara (Mulford \& Comiskey, 2002, 259);

Potcenjivanje obaveza je jednako „uspešan“ instrument prevara za iskazivanje veće neto imovine i veće dobiti. Obaveze prema dobavljačima, zaposlenima, obaveze po osnovu obračunatih rashoda i obaveze prema državi biće iskazane u nižem iznosu tako što će izostati njihovo priznavanje i priznavanje sa njima povezanim rashodima (Škarić-Jovanović, 2011, 221). Kako obaveze prema dobavljačima u ukupnim tekućim obavezama, po pravilu, imaju najveće učešće, a čvrsto su povezane sa promenom visine zaliha, promena relativnog odnosa rasta obaveza prema dobavljačima i rasta zaliha smatra se dobrim indikatorom moguće „igre finansijskim brojevima“ (Mulford \& Comiskey, 2002, 261);

Jedan od najlakših načina prikrivanja obaveza jeste svesno propuštanje njihovog knjiženja, tj. izostavljanje obaveza. Izvršioci ove prevare jednostavno uništavaju, skrivaju ili stavljaju sa strane dokumenta o obavezama i njima pripadajućim troškovima, ne knjiže ih i ne uključuju u finansijske izveštaje (Petković, 2010, 232). Propust $u$ evidentiranju obaveza ima istu svrhu - bez obaveza ne dolazi do dodatnih rashoda, niti do smanjenja imovine, kao ni do umanjenja kapitala koje se obično javlja (Singleton, Singleton, Bologna, \& Lindquist, 2006, 110). Određeni broj kompanija izostavljaju obaveze po osnovu dobijenih zajmova. Ovo je radikalan potez, i teško ga je sakriti, jer svaka pozajmica se - pored bilansa kompanije koja je uzela kredit - vidi i u bilansu kompanije ili banke koja je taj novac pozajmila. Međutim, opravdanje kompanija zbog neevidentiranja pozajmljenih sredstava je da je kredit uzeo vlasnik kao privatno lice, a ne kompanija kao pravno lice, ili da postoje tehnički problemi kod banke koji nisu omogućili evidenciju tog kredita. Ponekad, pojedine kompanije ne evidentiraju obaveze po osnovu dobijenih zajmova misleći da niko neće primetiti. Najčešći motiv skrivanja obaveza je izbegavanje prikazivanja visoke zaduženosti preduzeća, kako bi se dobili novi krediti, prevarili dobavljači, privukli investitori, i kako bi se održala cena akcija na tržištu kapitala.

Gotovina - Prevare vezane za gotovinu podrazumevaju uzimanje gotovine od poslodavca. Najčešće prevare sa gotovinom su:

Krađa gotovine - Da bi počinilac izvršio prevaru krađu gotovine, on se mora nalaziti u poziciji koja mu omogućava direktan kontakt sa gotovinom i sa gotovinskim tokovima kompanije - sa prilivima i odlivima gotovine. Metode krađe gotovine se mogu svrstati u dve osnovne grupe i to: prisvajanje gotovine „na kasi“ - ova manipulacija podrazumeva da se gotovina krade direktno iz blagajne preduzeća ili iz fiskalne kase u prodavnici, i prisvajanje gotovine „sa depozita" - sav novac dobijen od prodaje ili vršenja usluga preduzeća su dužna da na kraju dana uplate na svoj tekući račun. Dešava se da pojedinci prisvajaju jedan deo ovog novca;

Prevare $u$ vezi plaćanja gotovinom - Ovu manipulaciju je teško uočiti, jer radnje koje se preduzimaju spadaju u legitimne načine plaćanja. Problem je što su određeni delovi transakcija naplate i isplate gotovine fiktivni ili nerealni. Najčešće prevare u vezi plaćanja gotovinom su: prevare u vezi fakturisanja - ovom manipulacijom se lažnim fakturama izvlači gotovina iz preduzeća; prevare $u$ vezi obračuna zarada - koristeći fiktivne zaposlene, falsifikovanjem radnih sati i zarada, i falsifikovanjem iznosa provizije, ovim manipulacijama gotovina odlazi na nelegalan način iz preduzeća; prevare u vezi naknade troškova - gotovinom preduzeća se plaćaju nepostojeći poslovni rashodi; i prevare sa čekovima - suština ove manipulacije jeste da se falsifikuju čekovi u potpunosti ili određeni deo čeka (iznos, izdavalac, i sl);

Prisvajanje dela gotovine - Ova manipulacija se pojavljuje u preduzećima koja posluju trgovinom poput barova, restorana, benzinskih pumpi i maloprodajnih objekata. Kao ilustrativan primer može se navesti način na koje je Seigel Bugsy vodio poslove kada je osnovao nekoliko kazina u Las Vegasu. S. Bugsy je trebao da uzima gotovinu zarađenu tokom dana ili tokom nedelje, da prisvoji jedan deo za čikašku mafiju, 
da prisvoji jedan deo za sebe (neoporeziv novac) i da ostatak prijavi kao prihod. Ukoliko vlasnik, kao što je S. Bugsy, prisvoji određene iznose sa gotovine koja pristiže, a, zatim, ostatak evidentira u poslovnim knjigama, teško je primetiti takvu prevaru. Ovakva vrsta prevare najviše oštećuje državu, zbog neplaćenog poreza. Primer ovakve prevare jeste i prevara poznata kao „Crazy Eddie“ u kojojje porodica koja je posedovala kompaniju prisvajala milione dolara od maloprodajnih objekata za prodaju elektronike, ostavljajući samo onoliko koliko je potrebno da se prikaže minimalna dobit (Singleton, Singleton, Bologna, \& Lindquist, 2006, 119).

\section{MANIPULACIJE U IZVEŠTAJU O NOVČANIM TOKOVIMA}

Izveštaj o novčanim tokovima je danas sastavni deo redovnog godišnjeg skupa finansijskih izveštaja prakse redovnog finansijskog izveštavanja. Ovaj izveštaj omogućava sagledavanje performansi preduzeća iz drugačije perspektive, u odnosu na bilans stanja i bilans uspeha, pružajući detaljne informacije o prilivima i odlivima unutar poslovnih, finansijskih i aktivnosti investiranja. Na ovaj način izveštavanje o novčanim tokovima je $u$ funkciji ocene izloženosti preduzeća finansijskim rizicima. Prevare $\mathrm{u}$ finansijskim izveštajima se najčešće ostvaruju manipulacijom pozicija $\mathrm{u}$ bilansu stanja i bilansu uspeha. To je dovelo do toga da informacije sadržane $\mathrm{u}$ izveštaju o novčanim tokovima budu vredan i pouzdan informacioni resurs za donošenje poslovnih odluka. Informacije koje pruža izveštaj o novčanim tokovima su sigurnije, jer je jednostavnije manipulisati prihodima, rashodima, imovinom, obavezama, nego prilivima i odlivima novca. Generalno postoje dve osnovne metode za manipulisanje operativnim aktivnostima u izveštaju o novčanim tokovima:

- maksimiziranje novčanih priliva po osnovu poslovnih aktionosti - Novčani prilivi po osnovu poslovnih aktivnosti bi trebalo da uključe prilive iz poslovnih transakcija. Međutim, preduzeća mogu pokušati da u okviru ovih priliva uključe i prilive od prodaje imovine. U slučaju Enron-a, pozajmice od banaka su tretirane kao prilivi od poslovnih aktivnosti. Iako su ove stavke trebale da budu prikazane u okviru finansijskih aktivnosti, u ovakvim slučajevima, preduzeća pokušavaju da prošire definiciju onoga šta spada $u$ prilive od poslovnih aktivnosti, a, s druge strane, da suze šta spada u prilive od investicionih i finansijskih aktivnosti. Prikazivanjem što većeg broja priliva kao priliva iz poslovnih aktivnosti, preduzeće teži da prikaže što bolje rezultate poslovanja;

- minimiziranje novčanih odliva po osnovu poslovnih aktionosti - Preduzeća, uz pomoć ove metode vrše obrnuti postupak od metode maksimiranja priliva novca iz poslovnih aktivnosti. Preduzeća teže da što je moguće veći broj odliva po osnovu poslovnih aktivnosti ne prikažu ili da ih prebace $\mathrm{u}$ odlive po osnovu investicionih ili finansijskih aktivnosti, tako što pokušavaju da suze definiciju onoga šta spada u odlive od poslovnih aktivnosti, a, s druge strane, da prošire šta sve spada u odlive od investicionih i finansijskih aktivnosti. Razlozi su isti kao i kod prethodne metode, smanjivanjem broja odliva po osnovu poslovnih aktivnosti želi se prikazati preduzeće što uspešnijim (Jones, 2011, $61)$.

Po mišljenju pojedinih teoretičara postoje četiri najvažnije metode manipulacija novčanim tokovima u preduzećima, i to (Schilit \& Perler, 2010, 190):

- prebacivanje novčanih priliva po osnovu finansijskih aktivnosti u prilive po osnovu poslovnih aktivnosti;

- prebacivanje novčanih odliva po osnovu poslovnih aktivnosti $\mathrm{u}$ odlive po osnovu investicionih aktivnosti;

- „naduvavanje” novčanih tokova po osnovu poslovnih aktivnosti koristeći akvizicije ili prodajom dela ili celokupnog preduzeća;

- povećavanje novčanih tokova iz poslovnih aktivnosti koristeći dodatne „pomoćne“ aktivnosti.

Slika 2 prikazuje osnovne metode prebacivanja priliva u poslovne aktivnosti ili odliva iz poslovnih aktivnosti. 


\begin{tabular}{|c|c|c|c|}
\hline & Poslovne aktivnosti & Investicione aktivnosti & Finansijske aktivnosti \\
\hline Prilivi & $\begin{array}{l}\text { Naplate od kupaca } \\
\text { Naplate od kamata } \\
\text { Naplate po osnovu } \\
\text { dividendi }\end{array}$ & $\begin{array}{l}\text { Prodaja akcija u trgovačke } \\
\text { svrhe } \\
\text { Prodaja postrojenja/opreme } \\
\text { Otuđenje poslovanja }\end{array}$ & $\begin{array}{l}\text { Pozajmice od banaka } \\
\text { Ostale pozajmice } \\
\text { Izdavanje akcija }\end{array}$ \\
\hline Odlivi & \begin{tabular}{|l|} 
Plaćanje po osnovu \\
kupovine \\
Plate radnika \\
Plaćanje po osnovu poreza \\
Plaćanie kamate
\end{tabular} & $\begin{array}{l}\text { Kupovina nekretnina } \\
\text { Kupovina zemljišta } \\
\text { Poslovne akvizicije }\end{array}$ & \begin{tabular}{|l|} 
Otplate zajmova \\
Otkup akcija i udela \\
Plaćanje po osnovu \\
dividendi \\
\end{tabular} \\
\hline
\end{tabular}

Slika 2 Prevare sa novčanim tokovima: „,Robin Hud“ trikovi

Izvor: Schilit \& Perler, 2010, 194

\section{Prebacivanje novčanih priliva po osnovu finansijskih aktivnosti u prilive po osnovu poslovnih aktivnosti}

Preduzeća u pojedinim situacijama pribegavaju raznim manipulacijama kako bi prikazala što veće prilive po osnovu poslovnih aktivnosti. Jedna od metoda koja to omogućava jeste prebacivanje novčanih priliva po osnovu finansijskih aktivnosti u prilive po osnovu poslovnih aktivnosti. Tehnike za ovakvu vrstu prevare su:

evidentiranje prividnih novčanih priliva iz poslownih aktionosti po osnovu redownih bankarskih pozajmica - Ova manipulacija je ostvarena u preduzeću Delphi Corporation, kompaniji iz SAD-a, koja je tokom 2000. godine imala probleme u poslovanju, a godinu dana ranije izbačena je iz korporacije General Motors-a. Celokupna auto industrija u okviru koje je poslovala i Delphi Corporation, je bila u problemima, tako da je menadžment ove firme pokušavao na razne načine da manipuliše rezultatima poslovanja kako bi poslovanje preduzeća prikazao što uspešnijim. Tokom 2000. godine, posebno $\mathrm{u}$ četvrtom kvartalu, novčani tokovi po osnovu poslovnih aktivnosti su bili $\mathrm{u}$ minusu. Ovo je bio veliki problem za Delphi Corporation, zbog činjenice da su upravo prilivi iz poslovnih aktivnosti više puta isticani kao znak uspešnog poslovanja. U decembru iste godine, Delphi Corporation je ponudila banci (Bank One) na prodaju zalihe u vrednosti od
200 miliona dolara. Banka je odbila ovu ponudu, ali je Delphi Corporation ponudila mogućnost da banka otkupi ove zalihe, i da za nekoliko nedelja "proda" ponovo njima. Zauzvrat, Delphi Corporation će banci platiti određenu kompenzaciju u zavisnosti od prodajne vrednosti. U suštini, ovo je bila klasična kratkoročna pozajmica od strane banke koja $\mathrm{u}$ ekonomskom smislu zahteva kolateral (Delphi Corporation je kao obezbeđenje upravo dala pomenute zalihe). Ovu pozajmicu je trebalo prikazati kao pozajmicu od banke i kao povećanje novčanih tokova iz finansijskih aktivnosti. Međutim, Delphi Corporation je odlučila da ovu pozajmicu prikaže kao klasičnu prodaju zaliha banci u iznosu od 200 miliona dolara. Na taj način je, pre svega, manipulisala prihodima od prodaje, koje je povećala za 200 miliona dolara, ali je i lažno prikazala povećanje priliva iz poslovnih aktivnosti po osnovu prodaje zaliha. Ovom manipulacijom, Delphi Corporation je prikazala u svom izveštaju o novčanim tokovima iz 2000. godine ukupno 268 miliona dolara priliva po osnovu poslovnih aktivnosti, od kojih je realnih bilo samo 68 miliona (SEC Report, 2006). Ovo je primer $t z v$. duple manipulacije, kojima pribegavaju mnoga preduzeća. Kada preduzeće veštački uveća prihode od prodaje, istovremeno, uvećavaju se i prilivi po osnovu poslovnih aktivnosti. Međutim, mnogi kontrolori koji otkriju „naduvavanje” prihoda od prodaje zanemaruju ovu činjenicu, tako da ova vrsta manipulacije često ne biva uočena; 
povećavanje novčanih priliva iz poslownih aktionosti po osnowu prodaje potraživanja pre roka Kompanije često pribegavaju prodaji potraživanja kao korisnoj strategiji poboljšanja rezultata poslovanja. Sa ekonomskog aspekta, ovo je jednostavna transakcija, preduzeće traži investitora (najčešće banku) koji želi da otkupi njegova potraživanja. Zauzvrat, preduzeće dobija novac u visini tih potraživanja umanjen za određenu proviziju koju naplaćuje banka pri otkupu. Postavlja se pitanje kako tumačiti ovu transakciju sa stanovišta novčanih tokova. Najčešće se ova transakcija definiše kao priliv novca po osnovu finansijskih aktivnosti. Međutim, preduzeća često ovaj priliv novca definišu kao priliv po osnovu poslovnih aktivnosti, zbog činjenice da su najčešće u pitanju potraživanja po osnovu prodaje. Potrebno je imati u vidu da se prodaja potraživanja može izvršiti na dva načina: klasičnom prodajom potraživanja trećoj strani (najčěšé banka ili neka druga finansijska organizacija), što se drugačije naziva faktoring, ili prodajom potraživanja trećoj strani (finansijska organizacija) sa ciljem da se odmah kupi novi finansijski instrument tj. neka vrsta hartija od vrednosti, što se drugačije naziva sekjuritizacija. Tokom 2004. godine, američki farmaceutski distributer Cardinal Health je imao problema sa nedostatkom novca, pa je odlučio da izvrši prodaju određenog broja potraživanja. Do kraja godine, Cardinal Health je prodajom svojih potraživanja sakupio preko 800 miliona dolara. Ova prodaja je predstavljala osnovu povećanja priliva po osnovu poslovnih aktivnosti tokom 2004. godine, u ukupnom iznosu od 971 milion dolara u odnosu na prethodnu godinu (sa 548 miliona na 1,5 milijardi dolara). Cardinal Health je na ovaj način prebacio prilive po osnovu poslovnih aktivnosti iz budućeg perioda (koje bi ostvario naplatom prodatih potraživanja) u sadašnji, i na taj način stvorio tzv. „rupu“ u budućem prilivu gotovine po osnovu poslovnih aktivnosti (SEC Report, 2007). Zato je bitno da se prilikom analize priliva iz poslovnih aktivnosti primeti nagli rast, da se razmotri ne samo iznos povećanja, nego i razlog koji je doveo do tog povećanja;

"naduvavanje" novčanih priliva iz poslownih aktionosti naplatom lažnih potraživanja od kupaca - Da bi prikazalo što bolje rezultate poslovanja, američko preduzeće Peregrine Systems je odlučilo da izvrši „naduvavanje" prihoda prikazivanjem prodaje nepostojećim kupcima. Time je ovo preduzeće prikazalo ne samo lažne prihode već i lažna potraživanja po osnovu kojih je navodno ostvarilo ove prihode. Međutim, Peregrine Systems je pored naduvavanja prihoda od prodaje po osnovu lažne prodaje izvršilo i prodaju tih nepostojećih potraživanja koje je prikazalo u bilansu stanja. Banka je otkupila ova potraživanja, ali je rizik od naplate tj. nenaplate preuzeo Peregrine Systems. Sa ekonomskog stanovišta, ovo je klasična pozajmica od banke, jer je ovaj novac Peregrine Systems dobio od banke, a lažna potraživanja su uzeta kao osiguranje banke, pa je ovakav priliv novca trebalo prikazati kao priliv novca po osnovu finansijskih aktivnosti, a ne kao priliv novca od prodaje potraživanja tj. kao priliv novca iz poslovnih aktivnosti (Ketz, 2004).

\section{Prebacivanje novčanih odliva po osnovu poslovnih aktivnosti u odlive po osnovu investicionih aktivnosti}

Često korišćena metoda manipulacije novčanim tokovima jeste prebacivanje novčanih odliva po osnovu poslovnih aktivnosti u odlive po osnovu investicionih aktivnosti sa ciljem rasterećenja novčanih tokova iz poslovnih aktivnosti i prikazivanja što boljeg rezultata poslovanja preduzeća. Ova metoda manipulacije se može ostvariti korišćenjem sledećih tehnika:

"naduvavanje" novčanih tokova iz poslovne aktionosti pomoću tzv. "bumerang" transakcija - Američka kompanija Global Crossing bavila se izgradnjom podvodnih optičkih kablova koji su trebali da spoje preko 200 najvećih svetskih gradova. Međutim, kako se krajem 2000. i početkom 2001. godine projekat privodio kraju počele su da se javljaju sumnje da li će Global Crossing uspeti da pokrije velike troškove poslovanja i vrati već velike dugove po osnovu pozajmica. Global Crossing je na ove sumnje odgovarala da problem ne postoji i da je jedan od bitnih pokazatelja uspešnog poslovanja velika količina novca kojom preduzeće raspolaže. Global Crossing je imala unapred sklopljene mnoge ugovore, tako da je veliku količinu novca dobila kao avans i pre završenog posla, što je umnogome uvećalo prilive gotovine po osnovu poslovnih aktivnosti. Tokom 2000. godine, iako je Global Crossing imala gubitak od 1,7 milijardi dolara, 
u izveštaju o novčanim tokovima iskazala je pozitivne novčane tokove po osnovu poslovnih aktivnosti $\mathrm{u}$ iznosu od 911 miliona dolara (Fabrikant \& Romero, 2002). Ova informacija je umirila investitore. Međutim, u kasnijoj analizi uočilo se da je ovakav visok nivo priliva gotovine jednim delom bio lažno prikazan tzv. „bumerang" transakcijama. Pošto je većina kompanija koje su se $\mathrm{u}$ to vreme bavile telekomunikacijama bila u problemima, Global Crossing se sa ostalim kompanijama dogovorila da međusobno izvrše „bumerang“ transakcije, koje su podrazumevale da Global Crossing proda svoje proizvode drugim kompanijama, ali da, istovremeno, $\mathrm{u}$ istom iznosu otkupi razne proizvode od tih kompanija. Uticaj ovih transakcija na novčane tokove je bio takav da je Global Crossing prodaju proizvoda prikazivala kao priliv novca po osnovu poslovnih aktivnosti, dok je kupovinu dobara prikazivala kao odliv po osnovu investicionih aktivnosti, čime su rasterećeni novčani tokovi iz poslovnih aktivnosti;

neadekvatna kapitalizacija normalnih operationih troškova - Izvršiti kapitalizaciju operativnih troškova je jedna od najjednostavnijih operacija kojom se smanjuju rashodi i poboljšavaju rezultati poslovanja. Međutim, mnoga preduzeća zaboravljaju da pritom opterećuju novčane tokove, što može dovesti do negativno iskazanog novčanog toka. Poznat je primer preduzeća WorldCom koje je izvršilo jednu od najvećih prevara $\mathrm{u}$ finansijskim izveštajima $\mathrm{u}$ istoriji. Ova kompanija je izvršila kapitalizaciju operativnih troškova $u$ iznosu od nekoliko milijardi dolara, ali je, istovremeno, izvršila i manipulacije sa novčanim tokovima iz poslovnih aktivnosti. WorldCom je operativne troškove prikazao kao kupovinu imovine, i tako ih klasifikovao u izveštaju o novčanim tokovima u odlive po osnovu investicionih aktivnosti, a ne u poslovne aktivnosti. Na ovaj način je WorldCom reklasifikovao preko 5 milijardi dolara odliva gotovine tokom 2000. i 2001. godine iz poslovnih $u$ investicione aktivnosti (Beresford, Katzenbach \& Rogers, 2003);

\footnotetext{
"Naduvavanje" novčanih tokova po osnovu poslovnih aktivnosti koriščenjem akvizicije ili prodajom dela ili celokupnog preduzeća
}

Često, pri spajanju preduzeća putem akvizicije ili prodajom dela ili celokupnog preduzeća dolazi do manipulacije novčanih tokova. Na ovaj način se rešava problem ili negativno iskazanog novčanog toka $\mathrm{u}$ jednom preduzeću koje se spaja ili koje se prodaje, ili se postavlja dobra osnova za novo preduzeće koje je nastalo spajanjem. Najčešće korišćena tehnika za ovaj vid prevara jeste prenos odliva novca iz poslovnih aktivnosti u investicione aktivnosti pomoću akvizicije. Prilikom kupovine ciljnog preduzeća novčani tokovi tog preduzeća, pogotovu novčani tokovi iz poslovnih aktivnosti, su u većini slučajeva impresivni, pa investitori na osnovu njih donose zaključke da kompanije uspešno posluju. Međutim, istrage često pokazuju da su uspešni novčani tokovi bili rezultat prevara $\mathrm{u}$ finansijskim izveštajima. Svaka akvizicija donosi boljitak za novčane tokove kompanije koja je nastala preuzimanjem druge kompanije. Ukoliko je kompanija kupljena gotovim novcem, onda se to plaćanje evidentira $\mathrm{u}$ odlive po osnovu investicionih aktivnosti. Ako se plaća akcijama, onda i nema odliva novca. Sama akvizicija donosi kompaniji sticaocu mnoge druge benificije. Na primer, svaka prodaja koju izvrši ciljno preduzeće se $u$ finansijskim izveštajima kompanije koja je preuzela drugu evidentira i kao prihod od prodaje, ali i kao priliv novca po osnovu poslovnih aktivnosti. Međutim, najveća šansa za poboljšanje novčanih tokova putem akvizicije leži u preuzetim potraživanjima i imovini. Ta potraživanja i imovina su prilikom sticanja formirala određene troškove i odlive novca, ali je sve to nastalo pre akvizicije. Sada, posle akvizicije, naplatom potraživanja i prodajom imovine, prilivi novca se evidentiraju u izveštaju o novčanim tokovima, što znači da preduzeće evidentira priliv novca po osnovu poslovnih aktivnosti (naplatom potraživanja), ali ne i odlive, jer su oni nastali pre akvizije.

\section{Povećavanje novčanih tokova iz poslovnih aktivnosti koristeći dodatne "pomoćne“ aktivnosti}

Mnoga preduzeća često, u situacijama kada imaju problema sa novčanim tokovima, koriste tzv. "pomoćne" aktivnosti koje im pomažu da prevaziđu nastale probleme. "Pomoćne" aktivnosti koje preduzeća mogu da koriste su mnogobrojne, ali najčešće su: 
uvećavanje novčanih tokova po osnovu poslovnih aktivnosti usporavanjem tempa plaćanja obaveza - Ovo je najjednostavnija tehnika odlaganja plaćanja obaveza, naročito, prema dobavljačima, sa ciljem manipulacije novčanim tokovima. Na ovaj način se odlažu odlivi novca po osnovu poslovnih aktivnosti, najčešće na period od mesec dana. Na primer, obaveze za decembar tekuće godine odlažu se za januar naredne godine, i na taj način se u izveštaju o novčanim tokovima za ovu poslovnu godinu smanjuju odlivi novca. Međutim, treba napomenuti da se ova tehnika obično ne koristi na duži period, jer se ne može plaćanje obaveza odlagati u nedogled. Kada je Bob Nardelli tokom 2000. godine postavljen za top menadžera u američkoj kompaniji The Home Depot Inc, pred njega su postavljena velika očekivanja. Jedan od načina da ispuni ta očekivanja investitora, B. Nardelli je pronašao u uvećavanju novčanih tokova po osnovu poslovnih aktivnosti smanjivanjem tempa plaćanja obaveza prema dobavljačima. Tokom 2001. godine, B. Nardelli je uspeo da produži rokove plaćanja prema dobavljačima sa 22 dana na 34 dana, što je kompaniji donelo skok novčanih tokova iz poslovnih aktivnosti sa 2,8 milijardi dolara na 6 milijardi dolara na kraju 2001. godine. Ovaj veliki skok novčanih tokova je jednim delom ostvaren i smanjivanjem tempa kupovine zaliha, o čemu će kasnije biti više reči. Tokom 2002. godine, B. Nardelli je pokušao da održi visok nivo novčanih tokova, pre svega, produžavanjem roka plaćanja. Jednim delom je to uspeo, sa 34 na 41 dan, ali su novčani tokovi iz poslovnih aktivnosti na kraju 2002. godine ipak pali sa 6 milijardi na 4,8 milijardi dolara (Schilit \& Perler, 2010, 243);

uvećavanje novčanih tokova po osnovu poslovnih aktivnosti ubrzavanjem tempa naplate potraživanja Ovom tehnikom preduzeće može poboljšati novčane tokove ukoliko bude u mogućnosti da na neki način ubedi svoje kupce da plate obaveze pre nego što je rok naplate. Sa ekonomskog stanovišta, veća naplata potraživanja od kupaca je sigurno dobar pokazatelj. Tokom 2002. godine, američko preduzeće EDS je pregovorima sa svojim postojećim kupcima uspelo da unapred dobije 200 miliona dolara koje je trebalo da naplati na osnovu pruženih usluga $u$ naredne dve godine. Ipak, EDS nije bila iskrena prema svojim investitorima i nije im napomenula da je ovo povećanje novčanih tokova rezultat ubrzane naplate potraživanja i da se taj tempo neće održati u narednom periodu. Ova ubrzana naplata jeste dovela do naglog skoka novčanih tokova tokom 2002. godine, ali je, ipak, što se na kraju i pokazalo, bila rezultat kratkoročnih prevara sa ciljem prikazivanja što boljeg poslovanja preduzeća. Ovaj primer manipulacije ukazuje da pri analizi finansijskih izveštaja, kada se uoči ubrzana naplata potraživanja od kupaca to predstavlja dobar znak. Međutim, uvek treba biti obazriv kod donošenja zaključaka, i istražiti da li je ta ubrzana naplata rezultat uspešnog poslovanja, ili predstavlja oblik prevare;

uvećavanje novčanih tokova po osnovu poslovnih aktionosti smanjenjem obima kupovine zaliha - Preduzeće The Home Depot Inc. je tokom 2001. godine, kao što je ranije rečeno, uspelo da uveća svoje novčane tokove koristeći produženje roka plaćanja obaveza. Međutim, jednim delom, ovo povećanje novčanih tokova je ostvareno i smanjivanjem obima kupovine zaliha. Jednostavno, The Home Depot Inc. je smanjilo porudžbine od svojih dobavljača, tako što je nabavljalo manje zaliha nego ranije i to po svakoj prodavnici, tj. nije nabavljalo zalihe $\mathrm{u}$ onom tempu $\mathrm{u}$ kome je to radilo $\mathrm{u}$ prethodnom periodu. The Home Depot Inc. je uspelo da ovom tehnikom smanji odlive novca za kupovinu zaliha sa 1,1 milijardu dolara tokom 2000. godine na čak 166 miliona dolara tokom 2001. godine (Grow, 2007).

\section{METODE SPREČAVANJA PREVARA}

Otkrivanje prevara je neizbežno povezano sa sprečavanjem prevara, i oba aspekta zajedno obezbeđuju sistem za kontrolu prevara. Za uspešno sprečavanje prevara potrebno je uspostaviti adekvatno kontrolno okruženje u kome će svi zaposleni, posebno menadžment preduzeća, poštovati određene etičke kodekse ponašanja. Suština je da se $u$ poslovanju spreče svi oblici prevara, pa samim tim i manipulacije u finansijskim izveštajima. Najvažnije metode sprečavanja prevara su:

- formiranje i pravilno organizovanje interne kontrole - Interna kontrola predstavlja skup procedura ili pravila kojima se kontroliše 
poslovanje preduzeća. Efikasan sistem interne kontrole podrazumeva, tj. uključuje pouzdan računovodstveni sistem, adekvatne kontrolne politike i postupke i politike obezbeđenja adekvatne zaštite sredstava kompanije. On, takođe, zahteva jasno definisane politike računovodstva i finansijskog izveštavanja (Stefanović, 2000, 9). Za uspostavljanje interne kontrole odgovoran je menadžment preduzeća. Najčešći oblici kontrole koje koristi interna kontrola u svom radu su: preventivna kontrola - fokusirana je na zaštitu imovine i finansijskih podataka preduzeća, pokušavajući da spreči prevare; istražna kontrola - pokušava da istraži prevaru što pre je moguće; korektivna kontrola - obuhvata aktivnosti kojima se pokušava naći rešenje za prevaru koja je pronađena kako bi se sprečile buduće prevare;

- stvaranje poštenih uslova poslovanja - Pošteni uslovi poslovanja podrazumevaju uslove $u$ kojima zaposleni poštuju etičke principe, gde su menadžmentu ciljevi preduzeća, a ne lični, na prvom mestu i u kojima se rad zaposlenih ceni i poštuje. Jedan od prvih elemenata formiranja ovakvih uslova poslovanja jeste zapošljavanje poštenih ljudi. Potrebno je da preduzeća imaju dobar sistem provere zaposlenih, a posebno novozaposlenih. Stalna provera zaposlenih se u praksi pokazala kao odličan način provere zaposlenih (Albrecht \& Albrecht, 2004, 101). Drugi element koji doprinosi stvaranju poštenih uslova poslovanja jeste formiranje pozitivnog radnog okruženja. Da bi preduzeća bila manje osetljivija na prevare potrebno je putem dobrog korporativnog kodeksa ponašanja formirati kod zaposlenih očekivanja za pošten rad, stvoriti sistem "otvorenih vrata“ koji će zaposlenima omogućiti nesmetanu komunikaciju, posebno sa višim rukovodiocima, i na ključne pozicije $u$ preduzeću postaviti pozitivne i poštene ljude;

- obezbeđivanje obuke zaposlenih o opasnostima od prevara - Kod zaposlenih bi trebalo razviti svest o tome šta se smatra prihvatljivim, a šta neprihvatljivim ponašanjem. Obuka zaposlenih počinje upoznavanjem sa pojmom prevare. Cilj je da zaposleni shvate da je sprečavanje prevare važno za njih, kao pojedince pođednako, koliko i za preduzeće u celini. Obuka zaposlenih o opasnostima od prevara je bitna, jer su mnoga istraživanja pokazala da zaposleni mogu biti od ključnog značaja za otkrivanje i sprečavanje prevare u smislu dojava i pružanja informacija o mogućim prevarama;

- uspostavljanjem politika i procedura u preduzeću - Na osnovu politika, uspostavlja se interna kontrola u preduzeću, i određuje se koje akcije i transakcije nisu etičke. Prema tome, politika koja se tiče prevara i pažljivo izrađene računovodstvene politike u preduzećima predstavljaju osnovu procesa otkrivanja $\mathrm{i}$ sprečavanja prevara $\mathrm{u}$ poslovanju.

Osim prethodno navedenih opštih preventivnih mera za sprečavanje prevara, mnoga preduzeća koriste i brojne druge specifične preventivne mere. Postoji veliki broj ovakvih mera koje se mogu koristiti $u$ procesu sprečavanja prevara u poslovanju. Koje će se mere koristiti zavisi od mnogobrojnih faktora: veličine preduzeća, finansijskih mogućnosti, kadrovske osposobljenosti, karakteristike poslovanja preduzeća, zemlje u kojima posluje preduzeće, sistema razvijenosti interne kontrole, zakonskih obaveza, i slično. Neke od mera za sprečavanja prevara su:

- video nadzor - Nadzor se, pre svega, koristi kao mera za otkrivanje prevare, ali on može služiti i kao preventivna mera u sprečavanju prevare. Suština je da se video nadzor postavi na vidnim mestima kako bi zaposleni bili svesni da će svaki njihov pokušaj da ostvare prevaru biti snimljen i uočen;

- stalna prismotra - U okviru ove preventivne mere ključnu ulogu imaju interni revizori i ostale vrste kontrola. Stalnom prismotrom ne ostavlja se mogućnost pojedincima da ostvare prevaru. Međutim, praksa je pokazala da stalna prismotra, zbog finansijskih i ljudskih ograničenja, mora da se vrši u određenim vremenskim periodima. Postoji opasnost da počinioci prevara u tim periodima budu obazrivi, ali da u periodima kada ne postoji prismotra ostvare prevaru;

- $\quad$ sudski postupak koji se pokrene protiv počinioca prevara može ostvariti veliku korist za preduzeće. 
Sudski postupak protiv počinioca šalje snažnu poruku da ukoliko neko izvrši prevaru i bude uhvaćen preduzeće pokreće sudski postupka i traži određenu zatvorsku kaznu za počinioce. Samim tim sudski postupak se može posmatrati i kao preventivna mera protiv budućih prevara u preduzeću, jer svojom ozbiljnošću preduzeće pokazuje budućim počiniocima da se prevare ne shvataju olako;

- obavljanje čestih i nenajavljenih kontrola - U mnogim preduzećima se tačno zna period $u$ kome se obavljaju redovne kontrole, i postoji opasnost da se počinioci prevara pripreme da na razne načine prikriju ostvarene prevare. Zbog toga je bitno da se u preduzeću obavljaju česte nenajavljene kontrole (Singleton, Singleton, Bologna \& Lindquist, 2006, 186).

\section{ZAKLJUČAK}

Finansijski izveštaji preduzeća su važan i nezaobilazan izvor informacija za investitore i poverioce $u$ procesu donošenja odluka o alokaciji sredstava, pa samim tim moraju sadržati informacije koje su jasne, relevantne i uporedive. Nastojanja menadžera da rezultate poslovanja i finansijski položaj preduzeća ulepšaju i prikažu performanse boljim nego što one stvarno jesu dovela su do sastavljanja manipulativnih finansijskih izveštaja koji se mogu označiti jednim od glavnih sredstava kojim se izvršavaju prevare. Mnogobrojne prevare $u$ prethodnom periodu dovele su do pojave velikog broja finansijskih skandala koji su bili posledica lažnog finansijskog izveštavanja, što je dovelo do toga da je kontrola finansijskih podataka postala mnogo strožija i detaljnija.

Menadžment preduzeća je pod konstantnim pritiskom da ostvari što bolje rezultate poslovanja, posebno u uslovima finansijske krize. Ovaj pritisak prisiljava menadžment da sve više pribegava mnogim oblicima manipulacija u finansijskim izveštajima, kako bi prikazali rezultate poslovanja koji se od njih očekuju. Pored ovog pritiska, mnogi menadžeri u cilju postizanja ličnih interesa, dobijanja dodatnih bonusa ili izbegavanja otkaza, pribegavaju prevarama u finansijskim izveštajima. Tehnike formiranja lažnih finansijskih izveštaja su mnogobrojne, i može se manipulisati mnogim stavkama $\mathrm{u}$ finansijskim izveštajima (prihodi, rashodi, obaveze, imovina, novčani tokovi itd.). Ipak, praksa je pokazala da $\mathrm{su}$ prihodi i rashodi najčešće predmet prevara $\mathrm{u}$ finansijskim izveštajima. Razlog tome je, pre svega, njihova važnost za analizu poslovanja preduzeća, ali i postojanje mnogobrojnih tehnika za manipulisanje ovim elementima finansijskih izveštaja. Ipak, analizom velikog broja prevara primećuje se da su mnogi počinioci prevara pribagavali manipulacijama pozicija bilansa stanja, sa ciljem da na taj način utiču na rezultat poslovanja i finansijsku poziciju preduzeća. Činjenica je da svi oblici prevara na kraju ostave trag na pokazatelje u bilansa stanja, ali je $\mathrm{u}$ ovom radu akcenat stavljen na tehnike manipulacije koje direktno utiču na pozicije bilansa stanja.

Upravo analize koje su urađene $\mathrm{u}$ trećem delu ovog rada ukazale su da su manipulacije zalihama, obavezama i gotovinom tehnike manipulacija koje se najčešće koriste u bilansu stanja, i da ove manipulacije imaju dugotrajno negativni uticaj na rezultate poslovanja i imovinu preduzeća. Ovim je dokazana prva postavljena hipoteza u ovom radu. Druga hipoteza postavljena u ovom radu, da se tehnike manipulacija priliva i odliva novca $u$ izveštaju o novčanim tokovima teže otkrivaju i sprečavaju od ostalih oblika manipulacija, dokazana je analizom u četvrtom delu rada. Manipulacije novčanim tokovima je teže ostvariti, ali i teže i otkriti i sprečiti. Problem je što se manipuliše realnim novčanim tokovima, za razliku od prihoda i rashoda koji tek treba da se naplate. Upravo zbog toga manipulacijama sa prilivima i odlivima novca pribegavaju samo „iskusni“ prevaranti. Praksa je pokazala da počinioci ovakvih manipulacija vešto prikrivaju svoje tragove, i da su tehnike koje se koriste za izvršenje ovakvih prevara često na granici legalnih metoda za prikazivanje novčanih tokova preduzeća. Zato je teško otkriti ovakav vid manipulacija, i pri analizi ovakvih prevara potrebno je analizirati mnogo detaljnije poslovanje preduzeća, sagledati povezanost pozicija u različitim finansijskim izveštajima i koristiti različite tehnike otkrivanja prevara, kako bi se na pravi način ovakav vid manipulacija sprečio u budućnosti 
i time povratilo poverenje $\mathrm{u}$ informacije koje su prezentovane $\mathrm{u}$ finansijskim izveštajima.

Analiza manipulacija u bilansu stanja i izveštaju o novčanim tokovima i ukazivanje na potrebu za većom kontrolom elemenata ovih izveštaja je glavni doprinos ovog rada. Problem je što svi oblici kontrole najviše pažnju posvećuju analizi manipulacija rashodima i prihodima i time ne uočavaju izvršene manipulacije $u$ bilansu stanja i izveštaju o novčanim tokovima. Svi ovi izveštaji su povezani, i manipulacija izvršena u jednom izveštaju direktno ili indirektno utiče na sve ostale izveštaje. Analizom tehnika manipulisanja zalihama, obavezama, gotovinom, prilivima i odlivima novca ukazuje se na problem njihovog otkrivanja pa samim tim i sprečavanja.

\section{REFERENCE}

Albrecht, S., \& Albrecht, C. (2004). Fraud Examination and Prevention. Ohio: USA, Thomson-South-Western.

Beresford, D., Katzenbach, N., \& Rogers, C. (2003). Report of Investigation of the Board of directors of Worldcom. INC. retrived 20.05.2015, from http://www.sec.gov/Archives/edgar/ data/723527/000093176303001862/dex991.htm.

Grow, B. (2007). Out a Home Depot. retrived 21.05.2015, from http://www.bloomberg.com/bw/stories/2007-01-04/out-athome-depotbusinessweek-business-news-stock-marketand-financial-advice.

Dmitrović Šaponja, Lj., Milutinović, S. i Šijan, G. (2007, maj). Zloupotrebe u računovodstou - rizik objektionog finansijskog izveštavanja. Rad prezentiran na XII međunarodnom naučnom skupu SM 2007 Strategijski menadžment i sistemi podrške odlučivanju u strategijskom menadžmentu, Subotica, Republika Srbija: Ekonomski fakultet u Subotici Univerzitet u Novom Sadu.

Fabrikant, G., \& Romero, S. (2002). How Executives Prospered as Global Crossing Collapsed. retrived 15.05.2015, from http:// www.nytimes.com/2002/02/11/business/how-executivesprospered-as-global-crossing-collapsed.html.

Jakšić, D. i Vuković, B. (2012). Uticaj krize na manipulisanje finansijskim izveštajima. Rad prezentiran na 16. kongresu Saveza računovođa i revizora Republike Srpske. Banja Vrućica: Republika Srpska.

Jones, M. (2011). Creative Accounting, Fraud and International Accounting Scandals. London, England: John Wiley \& Sons.
Ketz, E. (2004). The Accounting CyclePeregrine Systems - Or the Lack of Them. retrived 15.05.2015, from http://accounting. smartpros.com/x46099.xml.

Malinić, D. (2009a). Prepoznavanje bilansnih rizika. Ekonomija preduzeća - Tajne bilansa: Menadžerski pristup. Beograd.

Malinić, D. (2009b). Cash-flow kao instrument otkrivanja poslovnofinansijskog rizika. Zbornik radova XL Simpozijuma 40 godina Računovodstva i Poslovnih finansija - dometi i perspektive, Beograd: Republika Srbija, Savez računovođa i revizora Srbije, 57-60.

Međunarodni standardi i saopštenja revizije. (2005). Beograd, Republika Srbija: Savez računovođa i revizora Srbije.

Milojević, M. (2009). Motivi i uslovi za finansijske prevare. Revizor, 46, 41-48.

Milojević, M. (2010). O rizicima finansijskog izveštavanja. Revizor, 52, 7-25.

Mulford, C., \& Comiskey E. (2002). The Financial Numbers Game, New York, NY: John Wiley \& Sons.

Petković, A. (2010). Forenzička revizija - Kriminalne radnje u finansijskim izveštajima, Novi Sad, Republika Srbija: Proleter A.D. Bečej.

Petrova, D. (2008). Korišćenje računovodstvenih procena $u$ manipulativnom finansijskom izveštavanju i odgovornosti revizora. Računovodstvo, 7-8, 23-34.

Schilit, H., \& Perler, J. (2010). Financial shenanigans - How to detect accounting gimmicks $\mathcal{E}$ fraud in financial reports (third edition). New York, NY: McGraw-Hill.

SEC Report. (2006). Charges Delphi Corporation and Nine Individuals, Including Former CEO, CFO, Treasurer and Controller, in Wide-Ranging Financial Fraud; Four Others Charged With Aiding and Abetting Related Violations, retrived 20.05.2015, from http://www.sec.gov/news/press/2006/2006-183.htm.

SEC Report. (2007). SEC Sues Cardinal Health, Inc. For Fraudulent Earnings and Revenue Management Scheme, retrived 20.05.2015, from http://www.sec.gov/news/press/2007/2007-147.htm.

Singleton, T., Singleton, A., Bologna, J., \& Lindquist, R. (2006). Fraud auditing and Forensic Accounting. New York, NY: Johne Wiley \& Sons.

Stančić, P., Dimitrijević, D. i Stančić, V. (2013). Forenzičko računovodstvo - odgovor profesije na prevare $\mathrm{u}$ finansijskim izveštajima. Teme, 4, 1879-1897.

Stefanović, R. (2000). Sprečavanje i otkrivanje lažnog finansijskog izveštavanja. Računovodstvo, 11, 3-11. 
Radulović, B. (2010). Procenjivanje i rizici finansijskog izveštavanja. Revizor, 52, 27-45.

Škarić Jovanović, K. (2011). Finansijski izveštaji kao instrument prevare. Rad prezentiran na VI kongresu računovođa i revizora Crne Gore.

Urošević, N. (2010). Neistiniti finansijski izveštaji - kome služe.
Privredni savetnik, 5, 50-59.

Wells, J. (2005). Principles of Fraud Examination. New York: NY, John Wiley \& Sons.

Zabihollah, R. (2002). Financial Statement Fraud - Prevention and Detection. New York, NY: John Wiley \& Sons.

Primljeno 12. juna 2015,

nakon revizije,

prihvaćeno za publikovanje 17. avgusta 2015.

Elektronska verzija objavljena 25. avgusta 2015.

Dragomir Dimitrijevićje docent na Ekonomskom fakultetu Univerziteta u Kragujevcu, gde je doktorirao u užoj naučnoj oblasti Računovodstvo, revizija i poslovne finansije. Izvodi nastavu na osnovnim i master akademskim studijama Fakulteta, na nastavnim predmetima Finansijsko knjigovodstvo i Forenzičko računovodstvo. Oblasti njegovog istraživačkog interesovanja su finansijsko izveštavanje, prevare $u$ poslovanju preduzeća i forenzičko računovodstvo. 


\title{
THE DETECTION AND PREVENTION OF MANIPULATIONS IN THE BALANCE SHEET AND THE CASH FLOW STATEMENT
}

\author{
Dragomir Dimitrijevic \\ Faculty of Economics, University of Kragujevac, Kragujevac, The Republic of Serbia
}

\begin{abstract}
Financial statements which consist of objective, real and reliable information represent the key basis for making many business decisions. If, when writing financial statements, certain manipulation techniques are used for displaying the best possible results of transactions, the quality of financial reports will be endangered. Many financial frauds have led to a great mistrust in the system of financial reporting and the profession of accounting and auditing, which are often accused of the emergence of fraud and losing trust in the reliability of financial information by many users and economic decision makers. These are the reasons why the paper discusses the techniques of manipulation in financial statements, especially in balance sheets and cash flow statements, since these forms of manipulation are harder to detect and prevent when compared to manipulations of revenues and expenses in the income statement.
\end{abstract}

Keywords: balance sheet, cash flow statement, financial reporting, manipulations, techniques of manipulations

JEL Classification: M48, K42 